\title{
TRAFFICKING OF MAINLAND CHINESE WOMEN INTO HONG KONG'S SEX INDUSTRY: PROBLEMS OF IDENTIFICATION AND RESPONSE
}

\author{
Robyn Emerton, * Karen Joe Laidler, ** and Carole J. \\ Petersen***
}

\section{Introduction}

Many governments in the Asia-Pacific region have undertaken obligations, under international and regional anti-trafficking instruments, to protect and assist women who are trafficked into prostitution. This article analyzes those obligations and then presents a case study of Hong Kong. The article argues that although Hong Kong has adopted credible protection policies, it is not applying them in practice, due to a widespread failure to identify victims of trafficking amongst sex workers. Thus, whilst the 2000s have been marked by a dramatic rise in the number of mainland Chinese women ${ }^{1}$ crossing the border to engage in sex work in Hong Kong, there

\footnotetext{
*Independent Researcher (UK), formerly Assistant Professor, Faculty of Law, University of Hong Kong.

**Professor, Department of Sociology, University of Hong Kong.

***Interim Director, Matsunaga Institute for Peace; Visiting Associate Professor, William S. Richardson School of Law, University of Hawaii at Manoa. The authors are grateful to the Hong Kong Correctional Services Department for allowing them access to, and facilitating their research at, their institutions and to all the women who agreed to be interviewed. They would also like to thank the Hong Kong Immigration Department, Police Force and Duty Lawyer Service for readily responding to their requests for information; the Global Alliance against Traffic in Women for sharing its experiences of interviewing trafficked persons; and Garlum Lau for her research assistance. The research was conducted with the assistance of a Small Project Grant from the University Grants Council, University of Hong Kong.

${ }^{1}$ In this article, references to "mainland China" are to the People's Republic of China [PRC], excluding the Special Administrative Region of Hong Kong and the Special Administrative Region of Macau. References to "mainland Chinese people" are to people resident in mainland China.
} 
has been no corresponding increase in the number of women identified by the authorities as victims of trafficking. ${ }^{2}$

This article draws upon in-depth interviews with women from mainland China who were incarcerated in Hong Kong for offences related to sex work. The interview pool included women who had worked under thirdparty management in Hong Kong, a group not previously studied. ${ }^{3}$ As well as providing important information on the experiences of migrant sex workers generally, the interviews presented an invaluable opportunity to examine whether any of the interviewees had been trafficked into Hong Kong, expanding on earlier studies that could not access trafficked women. ${ }^{4}$ Based on their accounts, 12 of the 58 women interviewed for this study would qualify as trafficking victims under our interpretation of the modern international definition of the term, contained in the Protocol to Prevent, Suppress and Punish Trafficking in Persons, Especially Women

${ }^{2}$ See discussion at pp. 60-63 below. The terms "victims of trafficking" or "trafficking victims" are adopted in this paper for consistency with the Trafficking Protocol, although the authors recognize that the term "trafficked persons" is preferred by advocates of the "pro-sex work" position (see discussion on p. 46 below).

${ }^{3}$ Whilst there is a growing body of research on the experiences of independent migrant sex workers in Hong Kong, interviewing an incarcerated population enabled us also to access women who had worked under third-party management, a group that is normally not accessible to researchers. On the experiences of independent migrant sex workers, see Veronica Pearson, "Business \& Pleasure: Aspects of the Commercial Sex Industry" in Pearson, Veronica \& Leung, Benjamin (eds), Women in Hong Kong, Hong Kong: Oxford University, 1995, 244-275; Zi Teng, Research Report on Mainland Chinese Sex Workers, Hong Kong: Zi Teng 2000; Travis Kong and Zi Teng, A Research Report on the Working Experiences of Hong Kong's Female Sex Workers, Hong Kong: Hong Kong Polytechnic University, 2003; Sui Lam Ko, Mainland Migrant Sex Workers in Hong Kong: A Sociological Study, MPhil submitted to Department of Sociology, University of Hong Kong, unpublished, 2003; and Action for Reach Out, A Survey on Hong Kong Police's Attitudes towards Female Sex Workers, Hong Kong: Action For Reach Out, 2005. On the experiences of all the migrant sex workers interviewed for our study, see Laidler et al., "Bureaucratic Justice: The Incarceration of Mainland Chinese Sex Workers in Hong Kong", 51 International Journal of Offender Therapy and Comparative Criminology, 68-83 (2007), and Emerton et al, The Imprisonment of Mainland Chinese Sex Workers in Hong Kong, Centre for Criminology, University of Hong Kong (2007) (available only in Chinese).

${ }^{4}$ Robyn Emerton, Trafficking of Women into Hong Kong: Preliminary Research Findings, Occasional Paper No.3 of the Centre for Comparative and Public Law (2001), Hong Kong: University of Hong Kong [hereinafter Emerton 2001]; Robyn Emerton "Trafficking of Women into Hong Kong for the Purpose of Prostitution: An Assessment of Law and Policy Responses in the Context of Recent International and Regional Developments", Nottingham Human Rights Law Review: Spring: Special Issue: Proceedings of Trafficking in Persons Conference, June 2003, 20-36; Robyn Emerton "Translating International and Regional Trafficking Norms into Domestic Reality: A Hong Kong Case Study", 10 Buffalo Human Rights Law Review, 215-260 (2004) [hereinafter Emerton 2004]. 
and Children, supplementing the Convention against Transnational Organized Crime [Trafficking Protocol]. ${ }^{5}$ As these women were not identified as trafficking victims by the Hong Kong authorities, the study raises important questions regarding the efficacy of Hong Kong's current laws and policies regarding potential trafficking victims. It is also hoped that the study will contribute to the limited research-based literature on trafficking within East Asia. ${ }^{6}$

Part 2 of the article discusses the nature and scope of state obligations to protect and assist victims of trafficking for prostitution under international and Asia-Pacific regional instruments, and also under general human rights law. ${ }^{7}$ It concludes that the progress made in recent anti-trafficking instruments is marred by the use of discretionary language to describe state obligations towards trafficking victims, and also by the ongoing debate about who should be considered a trafficking victim. Part I also summarizes Hong Kong's status as a Special Administrative Region of China (it is separated from the rest of China by a strictly regulated border) and Hong Kong's international and regional commitments to trafficking victims.

Part 3 sets out the methodology and context of the study, including the reasons for the recent surge in mainland Chinese sex workers in Hong Kong, and the law enforcement and immigration measures taken to deter such women from crossing the border. This section of the article also reports statistics on the number of women officially recognized as trafficking victims, and describes the law and policy response to this small group.

Part 4 discusses the interview findings. The accounts of the interviewees strongly suggest that the number of trafficking victims in Hong Kong is greater than presently recognized. The Hong Kong government has

\footnotetext{
${ }^{5}$ UN Doc A/55/383 (adopted 15 November 2000, entered into force 29 September 2003), supplementing the United Nations Convention against Transnational Organized Crime, UN Doc A/45/49 (adopted 15 November 2000, entered into force 23 September 2003).

${ }^{6}$ See, June JH Lee, "Human Trafficking in East Asia: Current Trends, Data Collection, and Knowledge Gaps", 43(1) International Migration, 165-201 (2005). Lee notes (at 165) the relative lack of research-based publications in East Asia, compared to South-East and South Asia. She assigns this (at 185) to the "enormous activities of donor and UN agencies" in South-East Asia, compared to the "relatively low volume of activities carried out by these agencies in North-East Asia", which, she notes, translates into a lack of funding for local researchers.

${ }^{7}$ This article does not address the trafficking of men or children, or trafficking for purposes other than prostitution.
} 
developed a highly standardized system, in order to quickly process and punish migrant women who enter Hong Kong to engage in sex work. The study indicates that this system impedes the effective identification of trafficking victims,-and threatens to eclipse Hong Kong's duties to trafficking victims. It is submitted that the Hong Kong authorities should accord greater priority to the identification of trafficking victims, and prioritize a human rights approach in their anti-trafficking laws and policies. The People's Republic of China [PRC] could facilitate this process by ratifying the Trafficking Protocol, on behalf of itself and Hong Kong.

\section{International and Regional Obligations to Protect and Assist Trafficking Victims}

Global concern about trafficking for the purpose of prostitution has led to the adoption, over the last one hundred years, of numerous international and regional instruments targeting this pernicious trade. It is not until recently, however, that those instruments have moved beyond co-operation and law-enforcement, and addressed the need to protect and assist trafficking victims.

\subsection{Early Trafficking Conventions and CEDAW}

By the Second World War, four international instruments had been adopted which specifically targeted trafficking for the purpose of prostitution. ${ }^{8}$ These four treaties were subsequently consolidated (and correspondingly amended $)^{9}$ by the Convention for the Suppression of the Traffic in Persons and of the Exploitation of the Prostitution of Others $(1949)^{10}$ [1949 Convention]. The concept of trafficking evolved in various

\footnotetext{
${ }^{8}$ These were the International Agreement for the Suppression of the White Slave Traffic (1904) 1 LNTS 83 [hereinafter the 1904 Convention], the International Convention for the Suppression of the White Slave Traffic (1910) 3 LNTS 275 [hereinafter the 1910 Convention], the International Convention for the Suppression of Traffic in Women of Full Age (1921) 9 LNTS 415 [hereinafter the 1921 Convention] and the International Convention for the Suppression of the Traffic in Women of Full Age (1933) 150 LNTS 431 [hereinafter the 1933 Convention].

${ }^{9}$ Protocol amending the International Agreement for the Suppression of the White Slave Traffic (1904) and the International Convention for the Suppression of White Slave Traffic (1910) (1949), 30 UNTS 23; and Protocol to amend the Convention for the Suppression of the Traffic in Women and Children (1921) and the Convention for the Suppression of the Traffic in Women of Full Age (1933) (1947), 53 UNTS 13.

${ }^{10} 96$ UNTS 271.
} 
ways under the early treaties. ${ }^{11}$ The 1904 and 1910 Conventions sought to combat only the forced recruitment and transportation of women for prostitution. In contrast, the 1933 and 1949 Conventions also treat the consensual recruitment and transportation of women into prostitution as trafficking. ${ }^{12}$ The 1949 Convention further aims to expunge the "evils of prostitution", ${ }^{13}$ calling on states to punish anyone involved in the "exploitation of prostitution, even with the consent of that person". ${ }^{14}$ In November 2007, the 1949 Convention had only 76 states party. ${ }^{15}$ Its low ratification status is often ascribed to its extension into the realm of prostitution per se (i.e. prostitution which does not involve movement across borders), which had long been considered to be a domestic, rather than international, matter. ${ }^{16}$

Trafficking was first referred to in a human rights context by the United Nations Convention on the Elimination of All Forms of Discrimination against Women (1979) [CEDAW]. ${ }^{17}$ Although CEDAW does not actually

\footnotetext{
${ }^{11}$ Conceptual developments include: addressing all trafficking for prostitution, and not only "white slave traffic"; incorporating trafficking within, as well as across, national borders; and recognizing trafficking in boys, as well as women and girls. For further detail on the early treaties, and the development of a human rights approach to trafficking, see in particular, Marjan Wijers and Lin Lap-Chew, Trafficking in Women Forced Labour and Slavery-Like Practices in Marriage, Domestic Labour and Prostitution, Utrecht, Bangkok: Foundation Against Trafficking in Women (STV) and Global Alliance Against Traffic in Women: 1997; Nora V. Demleitner, "Forced Prostitution: Naming an International Offence", 18 Fordham International Law Journal, 163-197 (1994); Stephanie Farrior, "The International Law on Trafficking in Women and Children for Prostitution: Making it Live Up to its Potential", 10 Harvard Human Rights Law Journal, 213 - 255 (1997); Janie Chuang "Redirecting the Debate over Trafficking in Women: Definitions, Paradigms, and Contexts", 11 Harvard Human Rights Law Journal, 64 - 107 (1998); Shelley Inglis "Expanding International and National Protections against Trafficking for Forced Labor using a Human Rights Framework", 7 Buffalo Human Rights Law Review, 55 - 104 (2001); and Elizabeth M. Bruch, "Models Wanted: the Search for an Effective Response to Human Trafficking", 40 Stanford Journal of International Law, 1-45 (2004).

12 Thus the 1949 Convention obliges states to punish any persons who "to gratify the passions of another procures, entices or leads away, for the purposes of prostitution another person, even with the consent of that person" (emphasis added), 1949 Convention, supra note 10, Article 1(1).

${ }^{13}$ Ibid, Preamble.

${ }^{14}$ Ibid, Article 1(2).

${ }^{15}$ United Nations Treaty Series: Multilateral Treaties Deposited with the Secretary General (status as of 15 November 2007).

${ }^{16}$ See e.g., Special Rapporteur on Violence against Women, its Causes and Consequences, Report on Trafficking in Women, Women's Migration and Violence Against Women [hereinafter Special Rapporteur VAW 2000 Report], 29 February 2000, UN Doc. E/CN.4/2000/68, para. 22.

${ }^{17}$ Adopted 18 December 1979; entered into force 3 September 1981.
} 
grant any rights to trafficking victims, ${ }^{18}$ Article 6 requires states to "take all appropriate measures, including legislation, to suppress all forms of traffic in women and the exploitation of prostitution of women"; however, neither term is defined. ${ }^{19}$ CEDAW has been widely ratified. In November 2007, it had 185 states parties (including all Asia-Pacific states), representing over $90 \%$ of United Nations members. ${ }^{20}$

Whilst some of these treaties contain basic protection provisions, none expressly addresses the human rights of trafficking victims. The 1910 Convention requires states (albeit "within legal limits, and as far as can be done") to entrust destitute trafficking victims to public or private charitable institutions pending repatriation, and to repatriate those trafficking victims who wish to be repatriated. ${ }^{21}$ The 1949 Convention obligates states to repatriate trafficking victims who wish to be repatriated, ${ }^{22}$ to pay for such repatriation if the victims and their families have insufficient means, ${ }^{23}$ and to make "suitable provisions for their temporary care and maintenance" pending such repatriation. ${ }^{24}$

In addition to the treaties and provisions which specifically address trafficking, a whole host of human rights instruments contain obligations which are relevant to trafficking, in particular, those prohibiting slavery, ${ }^{25}$ forced labour ${ }^{26}$ and torture, inhuman and degrading treatment, ${ }^{27}$ and those

\footnotetext{
${ }^{18}$ CEDAW mentions trafficking in Part I, together with its overview provisions, rather than expressing it as one of the rights enumerated in Parts II, III and IV of the treaty, see Bruch, supra note 11 , note 53 .

${ }^{19}$ CEDAW does not define "trafficking" or "exploitation of prostitution". Nor does General Recommendation No. 19 (Violence against Women) (1992), which comments on the trafficking provision (in paras 13 and 14), shed any more light on this. The General Recommendations are available at http://www.un.org/womenwatch/daw/cedaw/ recomm.htm.

${ }^{20}$ Division for the Advancement of Women, http://www.un.org/womenwatch/daw/cedaw/ states. htm.

${ }^{21} 1910$ Convention, supra note 8 , Article 3.

221949 Convention, supra note 10 , para $18(2)$.

${ }^{23} \mathrm{Ibid}$, para 18.

${ }^{24} \mathrm{Ibid}$, para $18(1)$.

${ }^{25}$ Universal Declaration of Human Rights [hereinafter UDHR], art 24, International Covenant on Civil and Political Rights (1966), 999 UNTS 171 [hereinafter ICCPR], art 8; International Covenant on Economic and Social Rights (1966), 993 UNTS 3 [hereinafter ICESCR], art 10(3); Slavery Convention (1926), 60 LTNS 253; Supplementary Convention on the Abolition of Slavery, the Slave Trade, and Institutions and Practices similar to Slavery (1956) 266 UNTS 40.

${ }^{26}$ Forced Labour Convention (1930) (ILO Convention No 29), Abolition of Forced Labour Convention (1957) (ILO Convention No 105).
} 
protecting refugees ${ }^{28}$ and migrant workers. ${ }^{29}$ As Obokata submits, an obligation to protect trafficking victims can be inferred from these human rights instruments, through the general duty to secure, ensure, or restore rights, and to provide remedies. ${ }^{30}$ Moreover, the prohibitions on slavery, forced labour and torture are recognized as jus cogens, ${ }^{31}$ and as such, are norms which every state must respect, regardless of its ratification of particular treaties. ${ }^{32}$ Thus the General Assembly, in its 2005 Resolution on Trafficking in Women and Girls, reminds all states of their obligation "to exercise due diligence to prevent, investigate and punish perpetrators of trafficking, and to provide protection to the victims" (emphasis added) ${ }^{33}$ The nature of this due diligence obligation is very general, however; it does not direct states on the particular measures that they must implement in order to protect trafficking victims. ${ }^{34}$ Specific protection provisions can only be found in the Trafficking Protocol, and regional anti-trafficking instruments. The nature and scope of these protection provisions is discussed below, as well as the fundamental issue of who is entitled to benefit from these protections, as a "victim of trafficking".

${ }^{27}$ UDHR, Article 5; ICCPR, Article 7; Convention against Torture and Other Cruel, Inhuman or Degrading Treatment or Punishment (1984), 1465 UNTS 85.

${ }^{28}$ Convention relating to the Status of Refugees (1951), 189 UNTS 150, as amended by the Protocol Relating to the Status of Refugees (1967) UNTS 267, including the principle of non-refoulement or non-return. On using international refugee law for the protection of trafficking victims, see Ryszard Piotrowitz, "Victims of People Trafficking and Entitlement to International Protection", 24 Australian Yearbook of International Law, 159-179 (2005).

${ }^{29}$ The Convention on the Protection of the Rights of All Migrant Workers and Members of their Families (1990), GA 45/158, Article 11(1) on slavery, and Article 11(2) on forced labour.

${ }^{30}$ Tom Obokata, "A Human Rights Framework to Address Trafficking in Human Beings", 34 Netherlands Quarterly of Human Rights, 379, at 391 (2006), referring for example to ICCPR, Article 2(3)(a).

31 See e.g., Human Rights Committee, General Comment 24 (Issues relating to Reservations made upon ratification or accession to the Covenant or the Optional Protocols thereto), CCPR/C/21/Rev.1/Add.6 (1994), para 8.

${ }^{32}$ A jus cogens norm is "a norm which is accepted and recognized by the international community of states as a whole as a norm from which no derogation is permitted", Vienna Convention on the Law of Treaties (1969), 115 UNTS 331 [hereinafter Vienna Convention], Article 53.

${ }^{33}$ General Assembly Resolution 59/166, Trafficking in Women and Girls, 10 February 2005, UN Doc A/RES/59/166, Preamble.

${ }^{34}$ See Obokata, supra note 30 , at 392 . Obokata discusses, at $392-395$, some general state obligations which can be applied more specifically to the protection of trafficking victims, such as observance of the principle of non-refoulement or non-return in relation to refugees; and the right of victims to participate in the investigation and prosecution of their traffickers, and to seek compensation, under the general right to redress. 


\subsection{The Trafficking Protocol}

The Trafficking Protocol was adopted in November 2000, and came into force on 25 December 2003. It has been widely endorsed, with 116 state parties as at 15 November 2007..$^{35}$ Numerous Asian-Pacific states have signed the Trafficking Protocol, although some are yet to ratify it. ${ }^{36}$ States that have not signed it include Afghanistan, Bangladesh, Bhutan, the PRC (including Hong Kong and Macau), Fiji, Malaysia, Nepal, North Korea, Mongolia, Pakistan, Samoa, Singapore, the Solomon Islands, Timor-Leste and Vietnam.

It is generally acknowledged that the Trafficking Protocol "will frame the contours of the international response [to trafficking] for the foreseeable future". ${ }^{37}$ Due to the Trafficking Protocol's wide international acceptance, it is submitted that any state's anti-trafficking laws and policies can usefully be gauged against the Trafficking Protocol's provisions, even if that state has not yet signed or ratified the Trafficking Protocol, and is therefore not legally bound by it. ${ }^{38}$ That is, the Trafficking Protocol provides a standard international benchmark, against which domestic antitrafficking responses can be measured.

As the first contemporary international instrument on trafficking, the Trafficking Protocol represents, in many ways, a landmark achievement. Whilst the earlier international treaties focused on trafficking for the purposes of prostitution, the Trafficking Protocol recognizes that modernday trafficking can also occur for other purposes, including (but not limited to) forced labour, slavery, servitude and the removal of organs. ${ }^{39}$ It also includes the first international definitions of "trafficking in persons" and "victims of trafficking in persons". Finally, the Trafficking Protocol is the first international instrument to take a holistic approach to trafficking. As well as requiring states to criminalize trafficking and take various law

\footnotetext{
${ }^{35}$ United Nations, Multilateral Treaties deposited with the Secretary-General, UN Treaty Database (status at 15 November 2007).

${ }^{36}$ Asian states which have signed, but not yet ratified the Trafficking Protocol include: India, Indonesia, Japan, South Korea, Sri Lanka and Thailand. Multilateral Treaties deposited with the Secretary-General, UN Treaty Database (status at 15 November 2007).

${ }^{37}$ See Bruch, supra note 11 , at 15.

${ }^{38}$ In respect of states which have signed (but not ratified) the Trafficking Protocol, Article 18 of the Vienna Convention, supra note 32, obliges them to refrain in good faith from acts that would defeat the object and purpose of the Trafficking Protocol in the period between signature and ratification.

${ }^{39}$ Article 3(a), Trafficking Protocol.
} 
enforcement measures, the Trafficking Protocol calls on states to protect and assist trafficking victims, and to address the root causes of trafficking.

A comprehensive review of the Trafficking Protocol is beyond the scope of this paper. ${ }^{40}$ The following discussion focuses, first, on the scope of the Trafficking Protocol's protection provisions, and second, on the category of persons who are entitled to benefit from those protection provisions under the Trafficking Protocol's definition of "victims of trafficking".

\subsubsection{The Limitations of the Trafficking Protocol's Protection Provisions}

The provisions of the Trafficking Protocol which require states to protect and assist trafficking victims are set forth in Articles 6 to 8. These provisions are far-reaching in scope, calling on states to protect the privacy and identity of trafficking victims and to ensure that they are given information on court and administrative proceedings, as well as the opportunity to present their views and concerns during those proceedings. States are also required to implement measures to provide for the physical, psychological and social recovery of victims of trafficking (including through housing, counselling, legal and medical assistance), and to protect their physical safety. States must provide legal avenues for compensation, and implement measures to permit trafficking victims to remain in their territory, temporarily or permanently, and to facilitate their repatriation. ${ }^{41}$

Much to the disappointment of human rights advocates, however, the Trafficking Protocol's protection provisions are only discretionary, and not mandatory. ${ }^{42}$ Whilst the Trafficking Protocol provides, for example, that states "shall adopt" legislation to criminalize trafficking, ${ }^{43}$ and "shall" take certain law enforcement measures, ${ }^{44}$ the protective provisions are extremely weak, requiring a state only to protect the privacy and identity

${ }^{40}$ For a comprehensive review of the Trafficking Protocol's provisions, see e.g. Ann Gallagher, "Human Rights and the UN Protocols on Trafficking and Migrant Smuggling: A Preliminary Analysis", 23 Human Rights Quarterly, 975-1004 (2001).

${ }^{41}$ For a critique of the nature and context of these provisions, see e.g. Special Rapporteur $V A W 2000$ Report, supra note 16, para 7; Kelly Hyland, "The Impact of the Protocol to Prevent, Suppress and Punish Trafficking in Persons, Especially Women and Children" 8(2) Human Rights Brief, 30 (2001); Human Rights Caucus Press Release, "NGO Positions on UN Protocols against Trafficking in Persons and Smuggling of Migrants" (2000), http://www.december18.net; and Ann Jordan, "Human Rights or Wrongs: The Struggle for a Rights-based Response to Trafficking in Human Beings" 10(1) Gender and Development 28, 33 (March 2002).

42 See e.g., Hyland, ibid, and Human Rights Caucus, ibid.

${ }^{43}$ Trafficking Protocol, Article 5.

${ }^{44}$ Ibid, Article 10. 
of victims "in appropriate cases and to the extent possible under its domestic law"; 4 to "consider" implementing measures to provide for the physical, psychological and social recovery of victims, ${ }^{46}$ and to "endeavour to provide" for the physical safety of victims whilst they are within its territory. Ditmore and Wijers argue that, in this sense, the Trafficking Protocol represents "a regression in international human rights law ... because it transfers rights into privileges that can be conferred or

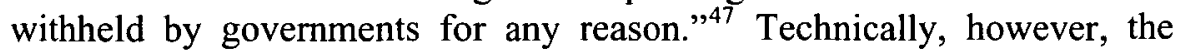
savings clause ensures that "nothing in the Protocol shall affect the rights, obligations and responsibilities of states under international law, including ... international human rights law".48 Nevertheless, it is certainly true that the Trafficking Protocol does not represent a substantive advance in the human rights protection of trafficking victims. As discussed below, disagreement about who qualifies as a "victim of trafficking" further undermines the practical effectiveness of the Trafficking Protocol's protection provisions.

2.2.2 Debates on the meaning of "Victims of Trafficking" under the Trafficking Protocol

The Trafficking Protocol calls on states to provide assistance and protection to the "victims of trafficking in persons". ${ }^{49}$ Thus the meaning of "victims of trafficking in persons" is directly linked to the definition of "trafficking in persons" contained in Article 3 of the Trafficking Protocol. This stipulates as follows:

(a) "Trafficking in persons" shall mean the recruitment, transportation, transfer, harbouring or receipt of persons, by means of the threat or use of force or other forms of coercion, of abduction, of fraud, of deception, of the abuse of power or of a position of vulnerability ... for the purpose of exploitation. Exploitation shall include ... the exploitation of the prostitution of others or other forms of sexual exploitation $\ldots$;

(b) The consent of a victim of trafficking in persons to the intended exploitation set forth in subparagraph (a) of this

\footnotetext{
${ }^{45}$ Ibid, Article 6(1).

${ }^{46} \mathrm{Ibid}$, Article 6(3).

${ }^{47}$ Melissa Ditmore and Marjan Wijers, The Negotiation on the UN Protocol on Trafficking in Persons, 2003(4) NEMESIS, at 86.

${ }^{48}$ Trafficking Protocol, Article 14.

${ }^{49}$ Ibid, Articles 6-8.
} 
article shall be irrelevant where any of the means set forth in subparagraph (a) have been used.

The Trafficking Protocol therefore acknowledges the wide spectrum of means by which a person might become a trafficking victim, including force, coercion, deception, and the abuse of power or the abuse of a position of vulnerability. Further, a person's consent to exploitation is deemed irrelevant if it was achieved through one of these stipulated means.

Although the very inclusion of the trafficking definition was a major break-through, achieved at the final hour after long and arduous negotiations, ${ }^{50}$ the definition has unfortunately failed to resolve the longstanding debate on the meaning of trafficking for the purpose of prostitution, namely whether or not all migration for the purpose of prostitution, or only migration into forced prostitution, constitutes trafficking.

Underlying the debate on the meaning of trafficking (and trafficking victims) are two fundamentally opposed feminist views of prostitution. Since these divergent approaches to prostitution and trafficking continue to divide opinion on the "correct" interpretation of the Trafficking Protocol's definition of "victims of trafficking", they are briefly summarized below. ${ }^{51}$

The first approach is generally referred to as the "radical feminist" or "abolitionist" approach to prostitution and trafficking. This stance was represented during the negotiations of the Trafficking Protocol by the International Human Rights Network, an alliance of non-governmental organizations [NGOs] led by the Coalition against Traffic in Women [CATW]. The abolitionist position is based on the premise that prostitution itself is a human rights violation, akin to slavery, and that no-one can give genuine consent to engage in prostitution. Advocates of this position do not distinguish between prostitution and trafficking. Since they maintain

\footnotetext{
${ }^{50}$ Jordan, supra note 41 , at 32.

${ }^{51}$ There are a number of excellent accounts of how these feminist approaches played out during the negotiations of the Trafficking Protocol, see e.g. Ditmore and Wijers, supra note 47, at 86; Gabrielle Simm, "Negotiating the United Nations Trafficking Protocol: Feminist Debates", 23 Australian Yearbook of International Law, 135-160 (2004); and Barbara Sullivan, "Trafficking in Women: Feminism and New International Law", 5(1) International Journal of Politics, 67-91 (2003). Much has also been written on the feminist debates surrounding prostitution and trafficking in general. Recent articles include: Joyce Outshoorn, "The Political Debates on Prostitution and Women", 12(1) Social Politics: International Studies in Gender, State and Society 141-155 (Spring 2005); and Kathy Miriam, "Stopping the Traffic in Women: Power, Agency and Abolition in Feminist Debates over Sex Trafficking", 36(1) Journal of Social Philosophy, 1-17 (Spring 2005).
} 
that all prostitution is inherently forced, they also regard all migration for prostitution as inherently forced. Thus abolitionists view all migrant prostitutes as victims of trafficking, and all third parties who assist women to travel and work in the sex industry as traffickers. The 1949 Convention is widely understood to advance this view of prostitution and trafficking. ${ }^{52}$

The second approach is usually termed the "materialist feminist", "pro-sex work" or simply "sex work" approach to prostitution and trafficking. This position was represented during the negotiations by the Human Rights Caucus, whose key members included the Global Alliance against Trafficking in Women [GAATW] and the International Human Rights Law Group. Under the sex work approach, prostitution is regarded as work (hence the preference for the term "sex work" over "prostitution"). Women are recognized as having the agency to freely choose, and consent, to engage in sex work. Proponents of this position draw a distinction between migration for sex work and trafficking. They regard migration for sex work as freely chosen and consensual, and trafficking as nonconsensual, since it involves the use of force (broadly defined to include coercion, deception, debt-bondage and the abuse of authority). Under a sex work approach, only migrant women forced or coerced into sex work through unlawful means are regarded as trafficked persons (the term "trafficked persons" is preferred by this group, to avoid further victimization of these persons).

The debate on the meaning of trafficking for the purpose of prostitution has not been confined to the NGO community and academic circles. Disparate views are also evident within the United Nations. In her 2000 report, the former Special Rapporteur on Violence against Women, Radhika Coomeraswamy, adopted a "sex work" approach to trafficking in her proposed new definition of trafficking. This definition, she argued, should move away from the historical characteristics of trafficking formalized in the 1949 Convention, which she considered "out-dated, illdefined and non-responsive" to the current realities of trafficking, ${ }^{53}$ and should be centred instead on the non-consensual nature of trafficking. ${ }^{54}$

\footnotetext{
52 Some commentators have, however, argued that the 1949 Convention can be interpreted otherwise, see e.g., Chuang, supra note 11, at 77; Demleitner, supra note 11, at 174.

${ }^{53}$ Special Rapporteur VAW 2000 Report, supra note 16, at para 10.

${ }^{54} \mathrm{Ibid}$, para 16. The Special Rapporteur proposed the following definition of trafficking: "the recruitment, transportation, purchase, sale, transfer, harbouring or receipt of persons: (i) by threat or use of violence, abduction, force, fraud, deception or coercion (including abuse of authority), or debt bondage; (ii) for the purpose of placing or holding such person, whether for pay or not, in forced labour or slavery-like practices, in a community other than
} 
This view was shared by the former High Commissioner for Human Rights. ${ }^{55}$ The Working Group on Contemporary Forms of Slavery, however, expressed concern, "that in [her 2000 report], the Special Rapporteur on Violence against Women offers a definition of 'trafficking' that is inconsistent with the principles of the 1949 Convention". ${ }^{56}$ It strongly recommended that the Ad Hoc Committee tasked with the elaboration of the Convention on Transnational Organized Crime ensure that the Trafficking Protocol does "not conflict with or otherwise undermine ... the 1949 Convention" and urged the Committee to ensure that the Trafficking Protocol was "not limited to forced or coerced trafficking but includes all trafficking, irrespective of the consent of the victim". 5

The definition of "trafficking in persons" that was ultimately adopted in the Trafficking Protocol was based on a compromise, which unfortunately left two core elements of the definition open to interpretation. First, the definition provides that a person may be trafficked not only through "force, coercion, deception and the abuse of power", but also through the "the abuse of a position of vulnerability" (see Article 3(a)). The travaux préparatoires (the official interpretative notes to the Trafficking Protocol) note that an "abuse of a position of vulnerability" can arise in a situation in which the person involved "has no real and acceptable alternative but to submit to the abuse involved." 58 This approach leaves open the questions of what constitutes a real and acceptable alternative, and whether economic circumstances are relevant. The interpretation of this new, rather nebulous, concept of "abuse of a position of vulnerability" could ultimately determine the threshold at which trafficking is recognized to occur (see the comments of the two Special Rapporteurs, discussed below). ${ }^{59}$

the one in which such person lived at the time of the original act described in (i)", ibid, at para 13.

35 The High Commissioner for Human Rights argued during negotiation of the Trafficking Protocol that it was imperative for the Protocol to distinguish between voluntary and forced prostitution, see eg., Informal Note by the United Nations High Commissioner for Human Rights, A/AC.254.16 (1999), para 12.

${ }^{56}$ Working Group on Contemporary Forms of Slavery, E/CN.4/Sub.2/2000/23, 21 July 2000, p.38, para 17.

${ }^{57}$ Ibid, p.38, paras 13 and 14 .

${ }^{58}$ Interpretative notes for the official records (travaux préparatoires) of the negotiation of the United Nations' Convention against Transnational Organized Crime and the Protocols thereto, A/55/383/Add.1 [hereinafter travaux préparatoires], para 63.

${ }^{59}$ See pp. $48-49$ below. 
The second problematic issue is that the definition of trafficking refers to trafficking for the purpose of "the exploitation of the prostitution of others" or "other forms of sexual exploitation". As in previous international instruments, these terms remain undefined, and the travaux préparatoires note that they are without prejudice as to how state parties address prostitution in their respective domestic laws. ${ }^{60}$ The effects of this compromise were soon apparent: GAATW argued that the Trafficking Protocol departs from the 1949 Convention, since it no longer requires governments to treat all adult participation in prostitution as trafficking, but allows them (if they so wish) to focus their domestic laws on forced prostitution. $^{61}$ CATW refuted this position, labelling it a "blatant misinterpretation" of the Trafficking Protocol. ${ }^{62}$ Viewing the final outcome as a "victory", CATW argued that the Trafficking Protocol "reverses the trend in recent years to separate prostitution from trafficking", ${ }^{3}$ and, "following in the footsteps of the 1949 Convention and CEDAW, requires governments to treat all adult participation in prostitution as trafficking". ${ }^{64}$

The meaning of the Trafficking Protocol's definition has also elicited different responses within the United Nations. In her final report, ${ }^{65}$ the former Special Rapporteur on Violence against Women recognizes that "the definition will evolve in its interpretation", ${ }^{66}$ but submits that, in the case of adults (which she contrasts to that of children), ${ }^{67}$ the "mere recruitment or transportation across borders for the purposes of prostitution is not enough as per the 1949 Convention. Some kind of force or abuse is required." ${ }^{68}$ The Special Rapporteur notes, however, that "the threshold for that abuse or force is extremely low and could involve the mere abuse of vulnerability, a category hitherto unknown in criminal law."69

${ }^{60}$ Travaux préparatoires, supra note 58, at para 64.

${ }^{61}$ GAATW, About GAATW: The UN Trafficking Protocol and its Limitations, pp. 6 and 10, http:/gaatw.net/publications/factpack.pdf (June 2002).

${ }^{62}$ CATW (Janice G. Raymond) Guide to the New UN Trafficking Protocol 2001, p.7, http://action.web.ca/home/catw/attach/un_protocol.pdf.

${ }^{63}$ CATW, Victory in Vienna, at http://www.utopia.pcn.net/puta3-i.html.

${ }^{64} \mathrm{Ibid}$, at 10.

65 "Integration of the Human Rights of Women and the Gender Perspective: Violence against Women", E/CN.4/2003/75, 6 Jan 2003 [hereinafter Special Rapporteur VAW 2003 Report].

${ }^{66} \mathrm{Ibid}$, at para 56.

${ }^{67}$ Under Article 3(c) of the Trafficking Protocol, children are considered to have been trafficked, even if none of the unlawful means in Article 3(a) have been employed.

${ }^{68}$ Special Rapporteur VAW 2003 Report, supra note 65, at para 56.

${ }^{69}$ Ibid. 
By contrast, the recently mandated ${ }^{70}$ Special Rapporteur on the Human Rights Aspects of the Victims of Trafficking in Persons, especially Women and Children, Sigma Huda, states in her 2006 report, $^{71}$ that the Trafficking Protocol "casts an extremely wide net in defining trafficking, one which arguably captures every present manifestation of prostitution".72 She rejects the pro-sex work position as "a profound misinterpretation of the current practice of prostitution throughout the world" because in her view, "it is rare that one finds a case in which the path to prostitution and/or a person's experiences within prostitution do not involve, at the very least, an abuse of power and/or an abuse of vulnerability." ${ }^{, 73}$ Thus, she maintains that "most prostitution is accomplished by one or more of the illicit means outlined in subparagraph (a) of the Trafficking Protocol, and therefore constitutes trafficking". ${ }^{4}$

In addition to this definitional uncertainty, the scope of the Trafficking Protocol's application is limited by its parent convention, the Convention against Transnational Organized Crime. Thus the Trafficking Protocol applies only where the trafficking is "transnational in nature" 75 and involves "an organized criminal group". ${ }^{76}$ Regrettably, it does not apply to all trafficking victims. By contrast, the 1949 Convention encompasses trafficking within and across national borders, and trafficking by any type of third parties. The former Special Rapporteur on Violence against Women viewed the development of the Trafficking Protocol in an organized crime context, as "a failure of the international community to

\footnotetext{
${ }^{70}$ The Special Rapporteur on the Human Rights Aspects of the Victims of Trafficking in Persons, especially Women and Children was appointed in 2004 by the Commission of Human Rights, for a three-year period, Human Rights Commission decision 2004/110, http://www.ohchr.org/english/issues/trafficking/.

71 "Integration of the Human Rights of Women and A Gender Perspective", E/CN.4/2006/62 (20 February 2006).

$72 \mathrm{lbid}$, para 48.

${ }^{73} \mathrm{Ibid}$, para 42.

${ }^{74} \mathrm{Ibid}$, para 38 .

${ }^{75}$ Trafficking Protocol, Article 4. Under the Convention against Transnational Organized Crime, Article 3, an offence is "transnational in nature" if: (a) it is committed in more than one State; (b) it is committed in one State but a substantial part of its preparation, planning, direction or control takes place in another State; (c) it is committed in one State but involves an organized criminal group that engages in criminal activities in more than one State; or (d) it is committed in one State but has substantial effects in another State.

76 "Organized criminal group" is defined, in Article 2 of the Convention against Transnational Organized Crime, as "a structured group of three or more persons, existing for a period of time and acting in concert with the aim of committing one or more serious crimes or offences established in accordance with this Convention, in order to obtain, directly or indirectly, a financial or other material benefit".
} 
fulfil its commitment to the protection of the human rights of women"., 7 Similarly, Jordan laments that "a unique opportunity to bring human rights to the foreground of the international legal response to trafficking was ... lost and another similar opportunity is highly unlikely". ${ }^{78}$

\subsection{Asia-Pacific Obligations to Protect Trafficking Victims}

There are no pan-Asian treaties against trafficking; nor does the region benefit from a regional human rights convention. ${ }^{79}$ However, three antitrafficking instruments have been adopted at the sub-regional level. This section discusses these instruments, which were adopted by the South Asian Association for Regional Cooperation [SAARC], the Association of South East Asian Nations [ASEAN] and a group of 18 Asian-Pacific countries which developed an Asian regional initiative against trafficking [ARIAT]. The Asia Pacific Forum of National Human Rights Institutions has also made important recommendations to its 17 members on the issue of trafficking, although these are not discussed here. ${ }^{80}$ Of the three subregional anti-trafficking instruments, the PRC and Hong Kong are only party to ARIAT (and neither has a national human rights institution). Nonetheless, the following section discusses all three instruments, both to contextualise developments in the region, ${ }^{81}$ and, in particular, to examine sub-regional positions on the meaning of trafficking victims, and the requisite measures to protect such victims.

\subsubsection{The SAARC Convention}

The Convention on Preventing and Combating Trafficking in Women and Children for Prostitution [SAARC Convention] $]^{82}$ is the only legally binding instrument on trafficking within the Asia-Pacific region. It was adopted in 2002, and came into force in 2005, following ratification by SAARC's then seven members, namely Bangladesh, Bhutan, India, the

\footnotetext{
${ }^{77}$ Special Rapporteur VAW 2000 Report, supra note 16, at para 7.

${ }^{78}$ Ann Jordan, supra note 41 , at 33.

${ }^{79}$ The Asia-Pacific region stands alone in having neither a regional human rights treaty, nor a regional human rights court (unlike the European, African and Inter-American systems).

80 'Asia Pacific Forum of National Human Rights Institutions' Advisory Council of Jurists Final Report: Consideration of the Issue of Trafficking", 4 Asia Pacific Journal on Human Rights and the Law, 145-160 (2003).

81 For an interesting review of the Asian-Pacific political discourse on trafficking, see Nancie Caraway, "Human Rights and Existing Contradictions in Asia-Pacific Human Trafficking Politics and Discourse", 14 Tulane Journal of International and Comparative Law, 295-316 (2006).

${ }^{82}$ Full text available at www.saarc-sec.org/old/freepubs/conv-traffiking.pdf.
} 
Maldives, Nepal, Sri Lanka and Pakistan. In April 2007, Afghanistan joined SAARC, but it is not clear whether it has signed or ratified the SAARC Convention to date. At the same time, the PRC was granted observer status to SAARC, ${ }^{83}$ which is an interesting development.

Unlike the Trafficking Protocol, the SAARC Convention addresses only trafficking for the purpose of prostitution, and not other forms of trafficking. ${ }^{84}$ However, its scope is not limited to trafficking in an organized crime context, or transnational context, as is the Trafficking Protocol. The SAARC Convention obliges state parties to co-operate in combating trafficking, to undertake measures to prevent, interdict and suppress trafficking, and to protect and assist trafficking victims. The $S A A R C$ Convention defines trafficking as the "moving, selling or buying of women and children for prostitution within and outside a country for monetary or other considerations with or without the consent of the person trafficked," 85 and requires states to criminalize "trafficking in any form" (emphasis added). ${ }^{86}$ When it comes to its protection provisions, however, the SAARC Convention defines "persons trafficked" as "women and children victimized or forced into prostitution by the traffickers by deception, threat, coercion, kidnapping, sale, fraudulent marriage, child marriage or any other unlawful means" ${ }^{87}$ Thus, for the purpose of criminalising trafficking, the SAARC Convention conceives of all migration for prostitution as trafficking (the abolitionist approach); yet it applies its protection provisions only to women forced into prostitution (the sex work approach). There is no reason why trafficking cannot be defined differently for these two purposes, but the differentiation has led NGOs to criticize the SAARC Convention for not making a clear distinction between trafficking and migration for prostitution. ${ }^{88}$

The SAARC Convention includes a range of protection provisions, although NGOs have called for these obligations to be more definite. ${ }^{89}$ For example, state parties are required to make "suitable provisions" for granting legal advice, counselling, job training and health care facilities for

${ }^{83}$ See Declaration of the Fourteenth SAARC Summit (3-4 April 2007, New Delhi), para 29, http://www.saarc-sec.org/data/summit14/ss 14declaration.htm.

${ }^{84}$ Furthermore, the SAARC Convention does not address the trafficking of men and boys.

${ }^{85}$ SAARC Convention, Article I(3).

${ }^{86}$ Ibid, Article III.

${ }^{87} \mathrm{Ibid}$, Article I(5).

${ }^{88}$ See e.g., Forum for Women Law and Development (Nepal), Comments on SAARC Convention, http://www.fwld.org.np/csaarchtml, and Advocacy Leaflet on the SAARC Convention http://www.fwld.org.np/ct.html.

${ }^{89}$ Ibid. 
the victims, without further detail. ${ }^{90}$ Similarly, states are left to "work out the modalities" for repatriation of the victims and, pending their repatriation, to "make suitable provisions" for their care and maintenance. $^{91}$

Unlike the Trafficking Protocol, the SAARC Convention expressly recognizes the important role which NGOs have to play in anti-trafficking efforts. It states, for example, that state parties "shall encourage" recognized NGOs "in efforts aimed at prevention, intervention and rehabilitation", 92 and "may authorize" them "to establish protective homes or shelters for providing suitable care and maintenance for the victims of trafficking"93 (states should also provide such homes or shelters). ${ }^{94}$ The $S A A R C$ Convention fails, however, to address certain key issues that are covered by the Trafficking Protocol. In particular, the SAARC Convention does not require states to grant trafficking victims immunity from prosecution for crimes committed as a result of being trafficked. It also does not provide for victim compensation, or situations in which trafficking victims do not wish to be repatriated. Responding to NGO criticisms, SAARC announced in 2003 that, once the SAARC Convention is ratified, it will make "direct efforts" to re-examine it and "to expand its scope using a rights-based approach", 95 but this review has not yet taken place.

\subsubsection{The ASEAN Declaration}

In 2004, ASEAN adopted a Declaration against Trafficking in Persons, Particularly Women and Children [ASEAN Declaration], ${ }^{96}$ as part of its efforts to combat transnational crime. ${ }^{97}$ The ASEAN Declaration has been signed by all of ASEAN's members, namely Brunei, Burma/Myanmar, Cambodia, Indonesia, Laos, Malaysia, the Philippines, Singapore, Thailand and Vietnam, but it is not legally binding on them. Although the

\footnotetext{
${ }^{90}$ SAARC Convention, Article $\mathrm{IX}(3)$.

${ }^{91} \mathrm{Ibid}$, Articles IX (1) and IX (2) respectively.

${ }^{92} \mathrm{Ibid}$, Article IX (5).

${ }^{93}$ Ibid, Article IX(4).

${ }_{95}^{94}$ Ibid, Article IX(3).

95 Bhutan Forward Moving Strategies (22 May 2003), http://www.unic.org.in/News/2003/pr/pr80.html.

${ }^{96}$ See $\mathrm{http}: / / \mathrm{www}$.aseansec.org/16793.htm.

${ }^{97}$ ASEAN Declaration, Preamble. See also: ASEAN Declaration on Transnational Crime (1997), Manila Declaration on the Prevention and Control of Transnational Organized Crime (1998), and Plan of Action to Combat Transnational Crime (1999), all available at ASEAN, http://www.aseansec.org/4964.htm.
} 
ASEAN Declaration does not define trafficking, it expressly reaffirms ASEAN's "unwavering desire to embrace the spirit behind the United Nations Convention against Transnational Organized Crime and its Protocols", 98 and thus might be taken to advance the Trafficking Protocol's definitions. ASEAN members declare that they will undertake "concerted efforts to effectively address ... trafficking in persons" through eight stipulated measures, but the whole declaration is diluted by a general caveat that they need do so only "to the extent permitted by their respective laws and policies". ${ }^{99}$ That is, ASEAN members do not commit to change any policies, yet alone laws, which are inconsistent with the ASEAN Declaration.

The ASEAN Declaration demonstrates little real commitment to the human rights dimension of trafficking by its members. In relation to victim protection, ASEAN members declare, subject to the general caveat mentioned above, that they will "distinguish victims of trafficking from their perpetrators" (it is surprising that such a basic provision is required), ${ }^{100}$ but, like SAARC, they do not declare that they will grant victims immunity from prosecution. ASEAN members further agree to "ensure that victims are treated humanely and provided with such essential medical and other forms of assistance deemed appropriate by the respective receiving/recipient country" 101 (emphasis added), and that they will "undertake actions to respect and safeguard the dignity and human rights of genuine victims of trafficking in persons"102 (emphasis added). The ASEAN Declaration fails to specify, however, what forms of assistance other than medical assistance must be provided, and who qualifies as a "genuine" victim of trafficking. The very use of the term "genuine" suggests an underlying suspicion of trafficking victims, and the demands they might make on ASEAN states.

Overall, the $A S E A N$ Declaration represents a step forward, particularly for a body which traditionally has been adverse to addressing human rights issues as part of its mandate. Yet it seems unlikely that the $A S E A N$ Declaration will have any real impact on its member states' antitrafficking laws or policies. Optimists might look to the new $A S E A N$

\footnotetext{
${ }^{98}$ Ibid.

${ }^{99}$ ASEAN Declaration, Preamble.

${ }^{100} \mathrm{Ibid}$, at para 5.

${ }^{101} \mathrm{Ibid}$.

${ }^{102} \mathrm{Ibid}$.
} 
Charter (adopted on 20 November 2007), ${ }^{103}$ as providing a foundation for a future rights-based approach to trafficking. But whether the Charter's express commitment to the protection and promotion of human rights in the region will prove to be real, and not mere rhetoric, remains to be seen. ${ }^{104}$

\subsubsection{ARIAT Action Plan}

In April 1999, 18 Asian-Pacific governments signed the Bangkok Declaration on Irregular Migration, ${ }^{105}$ which expresses concern about trafficking within the region, particularly by organized crimes groups (albeit only in the context of irregular migration). In March 2000, the same group discussed the human rights aspects of trafficking, at a meeting co-hosted by the Philippine and US governments. The group comprised Australia, Brunei Darussalam, Hong Kong (China), Japan, Cambodia, Thailand, Macau (China), Malaysia, Mongolia, New Zealand, Papua New Guinea, the PRC, Indonesia, Republic of Korea, the Philippines, Russian Federation, Singapore and Vietnam. Various international organizations and non-governmental organizations were also represented during the meetings, which culminated in the adoption of the Action Plan against Trafficking in Persons, Especially Women and Children for the AsiaPacific Region [ARIAT Action Plan]. ${ }^{106}$

Although it is not legally binding, the ARIAT Action Plan sets out an extensive set of recommendations to combat trafficking "in all its forms" 107 (and not just prostitution) within the region. In particular, its "Strategic Areas for Action" include a wide-range of proposals relating to the protection of trafficking victims. Many of these recommendations echo the provisions contained in the Trafficking Protocol. Signatories are required inter alia to protect the human rights of trafficking victims; to provide them with information and assistance; to protect their physical safety; to offer them shelter and economic, psychological, medical and legal assistance; to establish hotlines and foster relationships with NGOs in

103 The ASEAN Charter was adopted on 20 November 2007, see http://www.aseansec.org/21085.htm. The Charter resolves amongst other things to create an ASEAN human rights body.

${ }^{104}$ See e.g., Wayne Arnold, "Historic ASEAN Charter reveals divisions", International Herald Tribune, 20 November 2007, p. 3, http:/www.iht.com/articles/2007/11/20/asia /asean.php.

105 The full text of the Bangkok Declaration on Irregular Migration is available at http://www.thaiembdc.org/info/bdim.html.

106 The full text of the ARIAT Action Plan is available at http://secretary.state.gov/www/picw/trafficking/riarap.htm.

${ }^{107}$ ARIAT Action Plan, Chairman's Statement, para 3. 
order to increase reporting and identification of trafficking situations; to repatriate them and provide them with programs for reintegration; to ensure they have adequate avenues of redress; and to ensure the full and active participation of trafficked persons in the process of follow-up. The fundamental weakness of the ARIAT Action Plan is that it does not define trafficking or trafficking victims, leaving it up to individual governments to determine who should receive the benefit of its protection measures. Further, despite its initial promise, the ARIAT Action Plan remains relatively unknown, with little follow-up by the governments that signed it. ${ }^{108}$

\subsection{The Nature of Advances made in Victim Protection through recent International and Asia-Pacific Instruments}

The above discussion demonstrates the advances which have been made in recent international and Asia-Pacific regional anti-trafficking instruments, which now make specific (and in some cases, detailed) provision for the protection of trafficking victims.

The inclusion of such provisions is, in principle, a major development. However, the practical effectiveness of these provisions is seriously undermined by a lack of clarity as to the scope of state obligations. First, most of the instruments (the SAARC Convention being the exception) do not make clear who should be classified as a trafficking victim for protection purposes, either due to ambiguities in the definition of the term (the Trafficking Protocol), or due to the complete absence of such a definition (the ARIAT Action Plan, and arguably the ASEAN Declaration). ${ }^{109}$ State parties therefore have a significant level of discretion in how they define trafficking victims in their domestic laws and policies. Further, all the instruments, to varying degrees, employ discretionary language in describing state obligations to protect and assist trafficking victims, effectively allowing states to determine what (or, in some cases, if any), level of protection they will provide. As Fitzpatrick comments, "the Trafficking Protocol is not to be mistaken for a human rights treaty, as states ratifying it assume few additional binding

\footnotetext{
${ }^{108}$ Scant reference is made to the ARIAT Action Plan in the literature, although one of the stated objectives of the University of Hawaii Manoa Globalization Research Center conference on The Human Rights Challenge of Globalization in Asia-Pacific-US: Trafficking in Persons, Especially Women and Children (Hawaii, USA, 13-15 November 2002) was to build on the ARIAT Action Plan, which gave it some international prominence for a time.

${ }^{109}$ The ASEAN Declaration may be taken to adopt the Trafficking Protocol's definitions, see pp. 52-53 above.
} 
obligations towards trafficking victims". ${ }^{110}$ As a consequence, Jordan argues, "the focus now shifts to the national level", and "the burden of advocating for rights-protective national legislation and policies shifts to domestic NGOs"."11

In addition to these key issues, none of the international or regional instruments provides any guidance to states on how to identify trafficking victims. ${ }^{112}$ In the context of the Trafficking Protocol, Gallagher notes that the "resulting lacuna is likely to seriously compromise the practical value of the Protocol's protection provisions". ${ }^{113}$ Certainly, in our study, identification problems emerged as a central issue of concern.

\subsection{Hong Kong's International and Regional Commitments towards Trafficking Victims}

Hong Kong is an interesting case study, in part because it has made a commitment to protect trafficking victims, but also because it has a sophisticated legal system and greater resources than most governments in the Asia-Pacific region. Thus, one would expect that Hong Kong could be relatively successful in identifying and assisting victims of sex trafficking.

In 1997, Hong Kong ceased to be a British colony and became a Special Administrative Region of the PRC. Nonetheless, the border between Hong Kong and mainland China is strictly regulated and can only be crossed legally with a valid visa (the types of visas available to mainland Chinese people are described below). ${ }^{114}$ Hong Kong's common law legal system is largely separate from the PRC's legal system and, to some extent, Hong Kong has its own "international legal personality". ${ }^{115}$ Most of the international treaties that were previously extended to Hong Kong by the United Kingdom have continued to apply to it, ${ }^{116}$ including human rights

\footnotetext{
${ }^{110}$ Joan Fitzpatrick, "Trafficking as a Human Rights Violation: The Complex Intersection of Legal Frameworks for conceptualizing and combating Trafficking", 24 Michigan Journal of International Law (2002-3) 1143, at 1151.

111 Jordan, supra note 41 , at 33.

112 The High Commissioner for Human Rights, in Principles and Guidelines on Human Rights and Trafficking, stresses the importance of establishing reliable techniques to identify trafficking victims, E/2002/68/Add.1 (20 May 2002), Guideline 2.

${ }^{113}$ Gallagher, supra note 40, 995.

114 See pp. 60-61.

115 See Roda Mushkat, One Country Two International Legal Personalities: The Case of Hong Kong, Hong Kong: Hong Kong University Press, 1997.

116 Letters of notification of treaties applicable to Hong Kong after I July 1997, deposited by the Government of the United Kingdom of Great Britain and Northern Ireland and the
} 
treaties to which China itself is not a party. ${ }^{117}$ Hong Kong also frequently participates in international meetings and organizations under its own name. However, since Hong Kong is not a state, nor a member of the United Nations in its own right, it can only become party to post-1997 international treaties through the PRC's ratification.

Hong Kong is obliged under the 1904, 1910 and 1921 Conventions to combat trafficking and punish the perpetrators in circumstances where force or other abuse is used in the recruitment of women into prostitution (it is not, however, bound by the 1949 Convention, which classifies all facilitated migration for prostitution as trafficking). It is also bound by CEDAW to "suppress all forms of traffic in women". As discussed above, however, these instruments provide little in the way of victim protection. Whilst the more recent instruments do contain such protection, Hong Kong has only signed the non-binding ARIAT Action Plan, which does not specify who should be classified as a trafficking victim. Hong Kong is not bound by the Trafficking Protocol. For reasons that remain unclear, ${ }^{118}$ the $\mathrm{PRC}$ has ratified the Convention against Transnational Organized Crime, but has not signed or ratified the Trafficking Protocol, and has extended neither instrument to Hong Kong. Legally, Hong Kong is therefore free to define trafficking victims, and to respond to them, as it thinks appropriate.

As discussed below, Hong Kong outwardly demonstrates a serious commitment to protecting trafficking victims. In practice, however, it applies its protection policies to an extremely small number of persons. The government's primary goal is efficiently to process and punish

Government of the People's Republic of China with the Secretary-General of the United Nations on 20 June 1997, available at the Hong Kong Treaty Database, Centre for Comparative and Public Law, University of Hong Kong, http://www.hku.hk/ccpl/hktreaty/ database.html.

${ }^{117}$ The most noteworthy example is the ICCPR, which was applied to Hong Kong when it was a British colony and has been incorporated into Hong Kong's domestic law by virtue of Article 39 of the Basic Law and by the Hong Kong Bill of Rights Ordinance. The PRC has since signed (but not yet ratified) the ICCPR on its own behalf. For a discussion of the significant role that the ICCPR has played in Hong Kong's jurisprudence, see Carole J. Petersen "From British Colony to Special Administrative Region of China: Embracing Human Rights in Hong Kong", in Randall Peerenboom, Carole J. Petersen and Albert H. Y. Chen, eds, Human Rights in Asia: A Comparative Legal Study of Twelve Asian Jurisdictions, France, and the United States, London: New York: Routledge. 2006. On Hong Kong's constitutional framework, see Yash Ghai, Hong Kong's New Constitutional Order, Hong Kong University Press: Hong Kong, $2^{\text {nd }}$ ed, 1999.

${ }^{118}$ Research of English and Chinese language press and other relevant materials, and enquiries of contacts at the Foreign Ministry of the PRC, have not provided any explanations for this position. 
mainland Chinese sex workers, in the hope of deterring them from returning to Hong Kong. Whilst many governments in the Asia-Pacific region might sympathize with (and endorse) this approach, our study reveals that it seriously undermines Hong Kong's ability to identify and assist trafficking victims and should not be emulated.

\section{Methodology and Context of the Study}

This section explains the methodology and context of our study. It also discusses the reasons for the rapid increase in mainland Chinese sex workers in Hong Kong, and Hong Kong's law and policy responses to both migrant sex workers and trafficking victims.

\subsection{Methodology}

The study was conducted in two phases between 2004 and 2006. The first phase involved interviews with mainland Chinese women incarcerated in Hong Kong for criminal and/or immigration offences relating to their involvement in sex work. Our initial pool consisted of 75 mainland Chinese women who had been convicted, and were serving sentences for one or more of the following offences: soliciting for an immoral purpose; breach of condition of stay; remaining in Hong Kong without authority; possession of a forged identity document; and false statement to an immigration officer. ${ }^{119}$ From this initial pool, 17 respondents were categorized as invalid interviews, either because: (a) they had not been involved in sex work (13 respondents) ${ }^{120}$ or (b) their accounts were inconsistent and regarded as unreliable by the research team (4 respondents). This left 58 valid interviews.

As well as referring to the experiences of the broader sample for comparative purposes, this article makes in-depth reference to the interview transcripts for 12 respondents, whose circumstances indicate that they were "victims of trafficking" under the modern international definition of the term, contained in the Trafficking Protocol. We adopted the "pro-sex work" interpretation of the definition, and only classified women as trafficking victims where there was evidence of force, coercion, deception, or similar abuse in their recruitment, transport, or endconditions. (By contrast, abolitionists would regard all of these women as

\footnotetext{
${ }^{119}$ For a description of these offences, see p. 64 below.

${ }^{120}$ Some of the women had been convicted of "breach of condition of stay" for taking up other types of employment, such as domestic and construction work, whilst on a non-work permit. It was only through the interviews that we were able to determine whether the women had been involved in sex work.
} 
victims of prostitution, and would also consider them to be victims of trafficking, if some degree of third-party facilitation or management was present. $)^{121}$ The lack of a recognized definition for the term "abuse of a position of vulnerability" was problematic, and we acknowledge that this category of trafficking victim may be under-represented in our findings.

We did not, however, apply the parent convention's limitations to the definition. Strictly speaking, the Trafficking Protocol only applies to transnational trafficking by organized crime groups, but it is difficult to apply the concept of "transnational" to Hong Kong, since it is a part of the PRC. We would submit, however, that movements from mainland China to Hong Kong are substantially equivalent to transnational movements since the Hong Kong government treats women who cross the border without a valid visa as illegal migrants. Further, as discussed below, ${ }^{122}$ the Hong Kong government itself includes women from mainland China in its official statistics on trafficking.

The format of the interviews was informed by the experiences of a major anti-trafficking organization in interviewing trafficked persons, ${ }^{123}$ and the World Health Organization's Ethical and Safety Recommendations for Interviewing Trafficked Women. ${ }^{124}$ The interviews were done on a voluntary basis, lasted about one hour, and were conducted in the respondent's Chinese dialect - principally Mandarin and, in some cases, Cantonese. A separate room, or, in one institution, a curtained area, was provided to try to ensure privacy. A semi-structured open-ended questionnaire was used to elicit data on the women's general demographic profile, recruitment, mode of entry into Hong Kong, working conditions, and experience of the criminal justice system. The interviewer phrased questions in different ways to check for consistency in individual responses (and four interviews were subsequently rejected as unreliable). There was no other means to check the validity of the respondents' accounts, and we accept that some women may have deliberately adopted

${ }^{121}$ Interestingly, some of the respondents in the study arranged their own visas and travel to Hong Kong, and worked independently, soliciting custom on the street. Theoretically, abolitionists should regard these women as victims of prostitution only, and not as victims of trafficking, since no third party facilitation or management was involved.

122 See p. 61.

${ }^{123}$ Robyn Emerton met with the Global Alliance against Traffic in Women in Bangkok, Thailand, on 19 April 2004 to discuss their experiences of, and to obtain their advice on, interviewing trafficked women within an institutional setting.

${ }^{124}$ World Health Organization (Cathy Zimmerman and Charlotte Watts), WHO Ethical and Safety Recommendations for Interviewing Trafficked Women, Geneva, Switzerland: WHO, 2003. 
a narrative which was consistent with that of a trafficking victim, although it was not a truthful representation of their experience. Nonetheless, our analysis shows clear patterns and commonalities in the women's experiences, suggesting a relatively high level of reliability of the data as a whole.

Phase two of the study involved assessing the general validity and reliability of the data through secondary means. In July 2005, we discussed our findings with two NGOs that work with migrant (and local) sex workers in Hong Kong, and sometimes assist them at the police station and/or court. Our findings regarding the system by which migrant women are processed were consistent with the experiences of these two NGOs. Between July 2005 and April 2006, we also conducted observations of migrant sex worker cases in the magistrates' courts, and these also were consistent with our interviewees' memories of their court experiences. We then presented and discussed our findings at a Round Table in April $2006,{ }^{125}$ with a wide range of knowledgeable individuals, including senior police and immigration officers, magistrates, consular officials, academics and representatives of NGOs. The discussion at the Round Table, which was not confined to the trafficking cases, confirmed our overall conclusions on Hong Kong's criminal justice response to mainland Chinese sex workers. ${ }^{126}$ Further information was elicited in 2007 through correspondence with the Hong Kong Correctional Services Department, Immigration Department, Police Force and NGOs.

\subsection{Reasons for the rapid Increase in mainland Chinese Sex Workers in Hong Kong}

Despite reunification in 1997, the border between mainland China and Hong Kong remains in place, and is strictly controlled through a complex immigration regime. Most residents of mainland China must obtain a "two way permit" to visit Hong Kong. This carries one of four endorsements: business, visiting relatives, group tour, or individual visit. Only a business permit, which generally allows multiple 14-day visits within a three-month period, allows the holder to engage in specified work whilst in Hong Kong (but this does not include or permit sex work). The other types of permits strictly prohibit any form of work. A permit for visiting relatives allows a

\footnotetext{
125 Round Table, "Bureaucratic Justice: The Incarceration of Mainland Chinese Women Working in Hong Kong's Sex Industry", co-hosted by the Centre for Comparative and Public Law and Centre of Criminology, University of Hong Kong, 27 April 2006.

${ }^{126}$ See Laidler et al., supra note 3.
} 
maximum of three months' stay, whilst a tourist endorsement (whether group or individual) usually provides for a seven to 14 day stay.

In recent years, there has been a relaxation of the border between mainland China and Hong Kong, in that it is now easier to obtain a visa to visit Hong Kong. The "individual visit scheme", introduced in July 2003 as part of the "Closer Economic Partnership Arrangement" to encourage cultural and economic exchange between Hong Kong and mainland China, ${ }^{127}$ is a particularly significant development. Under this scheme, people from designated cities and provinces in the mainland are permitted to enter Hong Kong as independent tourists, rather than being obliged to join a tour group, as was previously the case. ${ }^{128}$ According to statistics released by the Hong Kong Immigration Department, ${ }^{129}$ the number of mainland visitors entering Hong Kong under one of the four visa categories gradually increased from approximately 0.5 million in 1997 to around 3.5 million in 2002. After the introduction of the individual visit visa in 2003, the number of mainland visitors rocketed to 11.4 million by $2006 .{ }^{130}$ By comparison, Hong Kong's population in 2006 was approximately 6.9 million. ${ }^{131}$

Although Hong Kong's high costs prevent it from being a destination for sex tourism, it has a substantial local sex market. ${ }^{132}$ Its high economic status in the region has made Hong Kong a popular destination for migrant sex workers over the years, attracting women from Asian countries (including India, Malaysia, Mongolia, the Philippines, Singapore, Uzbekistan and Vietnam) and further afield (for example, Columbia, Russia, Thailand and the United Kingdom). Until the 2000s, mainland Chinese accounted for a tiny fraction of Hong Kong's migrant sex workers. In 1993, less than 1\% (15 out of 1,231) of the migrant women arrested for sex work in one well-known sex worker district were mainland Chinese. ${ }^{133}$ In contrast, mainland Chinese now represent approximately

127 Hong Kong Tourism Commission (undated) "Visitor Information: Individual Visitor Scheme", http://www.tourism.gov.hk/english/visitors/visitors_ind.html.

128 Hong Kong Immigration Department, Year-end Briefing, 20 January 2004, http://www.immd.gov.hk/ehtml/20040120.htm.

${ }^{129}$ Hong Kong Immigration Department, Personal Communication, 9 May 2007.

${ }^{130}$ Ibid.

${ }^{131}$ Hong Kong Census and Statistics Department, Population and Vital Events (2007), at http://www.censtatd.gov.hk/hong_kong_statistics/.

${ }^{132}$ In 1999, it was estimated that one in seven Hong Kong men had visited a prostitute in the last six months, with half of those visits taking place in Hong Kong, Audrey Parwani, "One in Seven Makes Visits to Prostitutes", South China Morning Post, 6 May 1999, 3.

133 Kate Whitehead and Nuri Vittachi, After Suzie: Sex in South China, Hong Kong:

Chameleon Press, 1997, p.78. 
$97 \%$ of all women (both local and migrant) arrested in Hong Kong for suspected involvement in sex work. ${ }^{134}$ Clearly, the increased availability of visas to visit Hong Kong has had a direct impact on the number of mainland Chinese women coming to Hong Kong for sex work. A further pull factor is the continuing economic disparity between mainland China and Hong Kong. In 2006, China's gross domestic product per capita (purchasing power parity) was US\$7,600, compared to US\$36,500 in Hong Kong. ${ }^{135}$

Whilst some women (particularly second-timers) make their own travel and work arrangements, cross-border cooperation and organization have become integral to Hong Kong's sex industry, and constitute the driving force behind the importation of mainland Chinese sex workers by third parties. Prostitution syndicates and individual entrepreneurs - some with connections to Hong Kong and/or mainland triads ${ }^{136}$ - reap huge profits from organizing the women's documentation and entry into Hong Kong. They also profit from "managing" the women, usually out of "villas" (i.e. brothels or vice establishments), and sometimes out of karaoke bars, massage parlours, or hairdressing salons that act as commercial fronts for sex work. In May 2002, for example, it was reported that police had raided 77 vice establishments controlled by the largest prostitution syndicate in Hong Kong, which was linked to the $14 \mathrm{~K}$ triad society. Core syndicate members were arrested in both Hong Kong and mainland China, and most of the sex workers who were arrested had been smuggled in from the mainland. The syndicate was said to have a monthly turnover of HK\$10 million (US\$1.3 million) and police applied to the courts to freeze HK\$86 million (US\$1 1.2 million) in assets. ${ }^{137}$

These developments - the changes in immigration policies and the emerging economic opportunities, both for the women and third parties profiting from them - are the backdrop for understanding the phenomenon of mainland women working in Hong Kong's sex industry.

${ }^{134}$ Hong Kong Immigration Department, Personal Communication, 9 May 2007.

135 Central Intelligence Agency, World Fact Book: China and Hong Kong, (2007) http:www.cia.gov/cia/publications/factbook/index.html.

${ }^{136}$ The triads are organized crime groups operating in mainland China, Macau and Hong Kong. See generally Yiu-kong Chu "The Triads as Business", London, New York: Routledge, 2000 chapter 10 (Prostitution); and Benjamin Liu, "Hong Kong Triad Societies before and after the 1997 Change-over", Hong Kong: Net e-Pub, 2001.

${ }^{137}$ Clifford Lo, "Police arrest 213 in anti-vice blitz: triad syndicates smashed as 900 officers swoop in territory's biggest crackdown on prostitution", South China Morning Post, 8 May $2002,4$. 


\subsection{No Corresponding Increase in the Number of Trafficking Victims}

Given the huge increase in the number of migrant - predominantly mainland Chinese - women working in Hong Kong's sex industry since 2000 , one would expect to find a corresponding increase in the number of women trafficked into prostitution in Hong Kong. Yet available statistics do not reflect any such increase.

The authors have not been able to obtain any official statistics on trafficking cases prior to 2000 . Emerton's 2001 preliminary report into trafficking into Hong Kong was the first published research on this issue. ${ }^{138}$ Based on a press survey and interviews with community groups and consulates, Emerton identified 30 women known to have been trafficked into Hong Kong for prostitution between 1990 and $2000 .^{139}$ In all of these reported cases, the women had been deceived into coming to Hong Kong in the belief that they would be taking up other types of employment, and were then forced into sex work. Six of the 30 women were mainland Chinese, five of whom were known to have been smuggled illegally into Hong Kong. Between 2001 and 2006, the Hong Kong Police Force informed us that there had been only 16 reported cases of trafficking for prostitution, involving a total of 36 trafficked women. ${ }^{140}$ This amounts to an average of only six trafficked women per year. In 2006 (the only year for which the Police Force provided this breakdown), nine of the 12 trafficked women were mainland Chinese, two were Filipinas and one was Japanese. $^{141}$ We understand that these cases, like the earlier cases, primarily involved women who were deceived and then forced into prostitution. ${ }^{142}$

\footnotetext{
${ }^{138}$ Emerton 2001, supra note 4.

${ }^{139}$ Ibid.

${ }^{140}$ These comprised 4 women in 2001, seven in 2002, five in 2003, five in 2004, three in 2005 and 12 in 2006, Commissioner of Police, Hong Kong Police Force, Personal Communication, 27 June 2007.

${ }^{141}$ Ibid.

${ }^{142}$ In respect of the 2001-2003 cases, information elicited from meeting between Robyn Emerton, Principal Assistant Secretary for Security, and a number of top-ranking officials involved in addressing the various aspects of trafficking into Hong Kong, including officials from the Security Bureau, Police Force (Organized Crime and Triad Bureau) and Immigration Department, 31 July 2003 [hereinafter Trafficking Meeting 2003]; and in respect of the later cases, discussions at Round Table 2006, supra note 125.
} 


\subsection{Law and Policy towards Mainland Chinese Sex Workers}

The small number of women who are being identified as victims of trafficking does not mean that the Hong Kong officials are turning a blind eye to the sex industry or ignoring migrant sex workers. Indeed, since the early 2000 s, the Hong Kong government has responded to the increase in the number of mainland Chinese sex workers with strong deterrence measures, including strict enforcement of the laws regulating prostitution, and immigration laws. ${ }^{143}$

Hong Kong law largely reflects an abolitionist approach to prostitution, although it is not party to the 1949 Convention. Prostitution itself is not illegal in Hong Kong, but almost everything related to prostitution is prohibited under Hong Kong's criminal law, including: soliciting for an immoral purpose or loitering for the purpose of soliciting, ${ }^{144}$ putting up public signs advertising prostitution; ${ }^{145}$ and running a vice establishment, ${ }^{146}$ making it difficult for sex workers to work legally. Both local and migrant sex workers may be charged with any of these criminal offences, the most common being soliciting.

In addition to criminal offences, migrant sex workers may also be charged with immigration offences. Indeed, Hong Kong's immigration laws make it impossible for any migrant women lawfully to engage in sex work in Hong Kong. In 1993, the authorities announced that they would start to regard sex work as employment for immigration purposes. ${ }^{147}$ This announcement, however, did not represent any conceptual shift towards sex work, as the Hong Kong government does not recognize prostitution as work in any other circumstances, whether in relation to local or migrant women. The policy change simply gave the authorities an alternative basis on which to arrest migrant sex workers. Since work visas are never issued for sex work, and tourist permits and permits for visiting relatives prohibit the holder from taking up any type of employment, migrant women will automatically be in "breach of condition of stay" if they engage in sex work in Hong Kong. ${ }^{148}$ Those who enter without documentation (illegal entrants) may be charged with more serious offences, including: remaining

\footnotetext{
${ }^{143}$ As noted above, p. 56, Hong Kong's domestic law is different from that of the PRC.

${ }^{144}$ Crimes Ordinance, Laws of Hong Kong, Chapter 200, s 147.

${ }^{145}$ Ibid, s 147A.

146 Ibid, s 137.

147 Jimmy Leung, "Vice Squad to Step up Crackdown against Prostitution Rackets", South China Morning Post, 21 June 1994, 4.

${ }^{148}$ Immigration Ordinance, Laws of Hong Kong, Chapter 115, s 41.
} 
in Hong Kong without authority; ${ }^{149}$ using forged or altered documents; ${ }^{150}$ and using another person's identity documents, which constitutes the offence of "making a false statement to an immigration officer". ${ }^{151}$

As well as using local laws to deter mainland Chinese sex workers from coming to Hong Kong, the government introduced a black-list system in November 2002, whereby mainland Chinese women deported on suspicion of prostitution - i.e. regardless of whether they were charged or prosecuted - are banned from returning to Hong Kong for five years. ${ }^{152}$ As a result, the market in false identity permits grew, both to protect a woman's identity in case of arrest and to assist blacklisted women to re-enter Hong Kong. The government responded, in December 2004, by introducing a facial differentiation system at immigration control points, to detect discrepancies between a person's documentation and identity. ${ }^{153}$ Nonetheless, our interviews indicate that it still remains relatively common for a young woman to be given a false identity by the people who recruit her to come to Hong Kong. The woman may or may not be aware that this makes her vulnerable to prosecution for more serious offences and thus a longer prison term.

At the peak of arrests in 2003, more than 10,000 mainland Chinese women were arrested in Hong Kong for criminal and/or immigration offences related to sex work. ${ }^{154}$ Since 2003, the number of arrests of mainland Chinese women has decreased annually, to 5,800 in 2006. Hong Kong's Secretary for Security has attributed this to vigorous law enforcement and improved immigration control. ${ }^{155}$ Meanwhile, the number of mainland Chinese women admitted to Hong Kong prisons climbed steeply from 3,646 in 2000 to 11,794 in 2005 , and then dropped to 6,061 in $2006 .{ }^{156}$ Even with the recent decrease in 2006, mainland Chinese represented more than $75 \%$ of the total number of females admitted to Hong Kong prisons. ${ }^{157}$

${ }^{149}$ Ibid, s 38.

${ }^{150} \mathrm{Ibid}, \mathrm{s} 42(2)$.

${ }^{151} \mathrm{Ibid}, \mathrm{s} 42(1)$.

${ }^{152}$ Editorial, “The Vice Menace”, South China Morning Post, 11 December 2002, 18.

${ }^{153}$ Hong Kong Legislative Council, Official Records of the Proceedings of the Council of the Legislature of the Hong Kong Special Administrative Region, 29 June 2005, 8991.

${ }^{154}$ Hong Kong Immigration Department, Personal Communication, 9 May 2007.

155 Ibid.

156 Statistics provided by the Hong Kong Correctional Services Department, Personal Communication, 27 April 2007.

157 Statistics provided by the Hong Kong Correctional Services Department, Personal Communication, 3 May 2007. 


\subsection{Law and Policy towards Trafficking Victims}

Section 129 of Hong Kong's Crimes Ordinance ${ }^{158}$ makes trafficking persons to or from Hong Kong punishable with up to 10 years' imprisonment. Hong Kong therefore meets its international obligations to criminalize trafficking for the purpose of prostitution. Interestingly, trafficking is defined broadly for this purpose, as "bringing in another person into Hong Kong for the purpose of prostitution". It is not a defence that the "other person consented to being brought into Hong Kong, whether or not he or she knew it was for the purpose of prostitution or that he or she received any advantage therefor". The crime of trafficking is therefore committed simply by facilitating a person's entry into Hong Kong for sex work, even if that person fully consented to the arrangement, and no improper means were deployed to recruit them. Hong Kong does not restrict the crime of trafficking to trafficking for forced prostitution, as per the earlier trafficking treaties to which it is a party. Rather, its criminal law clearly reflects an abolitionist approach, whereby all facilitated migrant sex work is regarded as trafficking (as advocated by the 1949 Convention, to which Hong Kong is not a party). Significantly, however, this broad approach to trafficking is limited to the crime of trafficking - it is not carried through into Hong Kong's protection provisions for trafficking victims.

Hong Kong law does not confer on trafficking victims any statutory rights to protection or assistance. Rather, Hong Kong's response to trafficking victims has developed entirely as a matter of policy. When we asked the Commissioner for Police what definition of "trafficking victims" is used for the purpose of Hong Kong's protection policies, the Commissioner replied that "no definition of 'trafficked women' exists specifically for the purpose of providing protection and assistance to trafficked women". ${ }^{159}$

Clearly, the authorities do not regard all migrant sex workers who are brought to Hong Kong by third parties as trafficking victims for protection purposes. Thousands of migrant sex workers are arrested and imprisoned each year and our findings (discussed below) ${ }^{160}$ indicate that a significant percentage are brought to Hong Kong by third parties. Meanwhile, an average of only six women have officially been identified as trafficking victims each year since 2000 . In practice, the authorities' response to trafficking victims arises principally in the context of their law

\footnotetext{
${ }^{158}$ Chapter 200, Laws of Hong Kong.

${ }^{159}$ Commissioner of Police, Hong Kong Police Force, Personal Communication, 27 June 2007.

${ }^{160}$ See pp. 69-81.
} 
enforcement activities against traffickers. The Hong Kong government's official policy is to grant immunity from prosecution to women who agree to act as a prosecution witness against their traffickers, and then to repatriate them. ${ }^{161}$ In addition, the authorities have a good track record of assisting women who escape from brothels or are found by the police in obviously abusive situations of forced prostitution. These women are generally not charged with any offences, and are repatriated, even if they are not prepared to cooperate in the prosecution of their traffickers. ${ }^{162}$

On paper, Hong Kong's protection policies comply with almost all of the provisions contained in the Trafficking Protocol and ARIAT Action Plan, ${ }^{163}$ although none of the measures has been developed specifically for trafficking victims, and it is not clear to what extent these measures are implemented in practice. For example, the authorities report that a wide range of general government services are available to women identified as trafficking victims, including shelter at refuge centres, social security payments, medical and clinical psychology services and police/witness protection, ${ }^{164}$ although community organizations report that they are not aware of women having been offered any such government services (and the authorities maintain that trafficking victims rarely seek such assistance). ${ }^{165}$

Similarly, Hong Kong's general criminal procedure law contains various measures to protect the privacy and identity of witnesses in court proceedings, which can be implemented to protect trafficking victims in proceedings against their traffickers. The court may order that the name and address of a witness be withheld, ${ }^{166}$ permit the proceedings to take

\footnotetext{
${ }^{161}$ Trafficking Meeting 2003, supra note 142; see also United States, Department of State 2007 Trafficking in Persons Report: Hong Kong [hereinafter 2007 TIP Report], http://www.state.gov/g/tip/rls/tiprpt/2007/.

${ }^{162}$ Trafficking Meeting 2003, ibid; this policy is also mentioned in the United States, Department of State 2006 Trafficking in Persons Report: Hong Kong [hereinafter 2006 TIP Report], http://www.state.gov/g/tip/rls/tiprpt/2006/.

${ }^{163}$ One area in which Hong Kong's position is relatively weak, is that there is no provision for women to remain in Hong Kong if it would be unsafe for them to return home, as recommended in the Trafficking Protocol (Article 7). As Hong Kong is not a party to the Convention Relating to the Status of Refugees, trafficking victims cannot seek asylum in Hong Kong. For a more detailed review of Hong Kong's protection policies, as compared with the Trafficking Protocol and ARIAT Action Plan provisions, see Emerton 2004, supra note 4 , at 245-247 and 252-259.

164 Trafficking Meeting 2003, supra note 142; Emerton 2004, supra note 4, at 252-253; 2007 TIP Report, supra note 161.

${ }^{165}$ Emerton 2004, supra note 4, at 253.

${ }^{166}$ Criminal Procedure Ordinance, Chapter 221, Laws of Hong Kong, s 123(2).
} 
place in closed court if this is deemed to be in the interests of justice, ${ }^{167}$ and allow the witness to testify from outside the court by way of live video-link if she is deemed to be a "witness in fear". ${ }^{168}$ The authors are not aware, however, of any trafficking cases in which these measures have been implemented.

Trafficking victims may also obtain compensation from their traffickers under the courts' general power to order a convicted offender to compensate the victim of a crime. ${ }^{169}$ They may also pursue a private right of action against their traffickers, for example, under the torts of false imprisonment, assault or battery, ${ }^{170}$ although the authors are not aware of any trafficking victims obtaining compensation through either means.

The services and protections available to trafficking victims in Hong Kong are, therefore, technically very commendable. Indeed, Hong Kong's antitrafficking efforts are generally well regarded, both regionally and internationally. For example, Hong Kong has consistently received "tier one" status in the United States' annual Trafficking in Persons Report ${ }^{171}$ for fully complying with the United States' minimum standards on trafficking, ${ }^{172}$ including its protection provisions for victims of "severe forms of trafficking". ${ }^{173}$ Our study shows, however, that, in practice, the

${ }^{167} \mathrm{Ibid}, \mathrm{s} 123(1)$.

${ }^{168} \mathrm{Ibid}$, s 79B(4), which defines such a witness, in section $79 \mathrm{~B}(1)$, as a "witness whom the court hearing the evidence is satisfied, on reasonable grounds, is apprehensive as to the safety of himself or any member of his family if he gives evidence".

${ }^{169} \mathrm{Ibid}, \mathrm{s} 73$.

${ }^{170}$ For the requirements of these torts, see Rick Glofcheski, Tort Law in Hong Kong (Hong Kong: Sweet \& Maxwell Asia, 2002), 425-443.

${ }^{171}$ Countries fully complying with the minimum standards are placed in "Tier 1"; countries making significant efforts to bring themselves into compliance are placed in "Tier 2" (including a Special Watch List); and countries which have failed to make such efforts are placed in "Tier 3".

${ }^{172}$ United States, Victims of Trafficking and Violence Protection Act of 2000, Pub.L. No 106-386, 114 Stat. 1464. The Act's protective provisions (Articles 6-8) include protecting victims of "severe forms of trafficking in persons", encouraging their assistance in the investigation and prosecution for trafficking, and ensuring "that victims are not inappropriately incarcerated, fined, or otherwise penalized solely for unlawful acts as a direct result of being trafficked."

${ }^{173}$ The initial Trafficking in Persons Report was criticized for its "omissions", "misconceptions" and "distortions", see Anne Gallagher, "Trafficking in Persons Report", 23 Human Rights Quarterly 1135-1141 (2001) (book review), at 1139. However, its credibility seems to be improving, and it clearly holds political influence, in particular, since its sanctions for third tier countries came into play in 2003, see US Victims of Trafficking and Violence Protection Act of 2000, ibid, s 110; TIP Report 2007, supra, note 161; "Introduction"; Janie Chuang, "The United States as Global Sheriff: Using Unilateral Sanctions to combat Human Trafficking", 27 Michigan Journal of International Law, 437, 
number of cases in which the Hong Kong authorities actually classify women as trafficking victims is very small. It appears that the government's intense focus on deterring mainland Chinese women from engaging in prostitution in Hong Kong threatens to eclipse its human rights obligations to trafficking victims.

\section{Interview Findings}

As noted above, ${ }^{174}$ no research has been published to date on the experiences of trafficking victims in Hong Kong. By describing the personal accounts of the 12 women in our study whom we classified as trafficking victims (but who were not identified as such by the Hong Kong authorities), we hope to contribute to a better understanding of modern-day trafficking into Hong Kong, and to help inform future law and policy development.

\subsection{Socio-demographic Characteristics of Trafficking Victims}

Interestingly, the socio-demographic characteristics of the 12 potentially trafficked women were consistent with the broader sample of 58 women. Nothing stood out which might explain their particular vulnerability to trafficking, such as age, education level, rural/city background, or income.

The women's median age was 20 . Ten women $(83 \%)$ had received a primary or junior secondary school education, and two had attended high school. Nine of the women (75\%) were originally from the southern region of China, two were from the east, and one from the north. Eleven of the women $(92 \%)$ had grown up in rural areas, but half had worked in a city before coming to Hong Kong. Prior to coming to Hong Kong, one woman was a housewife, and two had recently left school. The rest were employed in factories (4 respondents), or in the service industry (4 respondents), i.e. in beauty salons and massage parlours, as waitresses or sales ladies. The factory workers earned about RMB500 (US\$65) per month, ${ }^{175}$ whilst those in the service industry earned around RMB1000 (US\$130) per month. The only notable difference from the overall sample was that none of the 12 trafficked women had worked in Shenzhen's entertainment industry prior to coming to Hong Kong, compared to $24 \%$ of the total sample. Shenzhen is a major city in southern mainland China, on the border with Hong Kong.

474-483 (2005-2006); and Mohamed Y. Mattar, "Monitoring the Status of Severe Forms of Trafficking in Foreign Countries: Sanctions Mandated under the US Trafficking Victims Protection Act", 10(1) Brown Journal of World Affairs, 159-179 (Summer/Fall 2003).

${ }^{174}$ See p. 36 above.

${ }^{175} 1$ RMB and HK\$1 = approximately US\$0.136 (exchange rates as at November 2007). 
It may be that women working in Shenzhen's entertainment industry are more knowledgeable about Hong Kong's employment opportunities and its sex industry, and therefore less vulnerable to trafficking, than those from elsewhere in mainland China.

\subsection{The Nature of Modern Day Trafficking into Hong Kong}

The majority of the 12 women were recruited by acquaintances from their village/town; only one was recruited by a stranger. One woman insisted that she had only intended to sightsee and shop in Hong Kong. However, most of the women in this category readily admitted that they had planned to work in Hong Kong, but were deceived about the nature of the job. They were generally promised service industry jobs, including waiting on tables, foot massage, car washing, hairdressing and cleaning. Two of the women specifically said that they knew that working in Hong Kong on a tourist permit or visiting relatives permit was illegal, but it was not clear from the other women's accounts whether or not they knew this.

Most of the women in our broader sample, and all of the 12 trafficked women, reported financial considerations as the primary factor influencing their decision to engage in sex work (or other work which ultimately transpired to be sex work) in Hong Kong. Some of the women said that they were driven by urgent and dire economic emergencies, whilst others believed that this opportunity could offer higher earning potential than their current jobs in mainland China. Indeed, whilst many of the respondents in the broader sample were arrested before making a profit, others reported what they regarded as significant earnings on their visit. One woman earned HK $\$ 2,000$ (about US $\$ 255$ ) on her first day, and many earned between HK\$5,000 (US\$640) and HK\$8,000 (US\$900) before arrest. One woman reported earning $\mathrm{HK} \$ 80,000$ (US\$10,000) on a previous visit.

Five of the 12 trafficked women were brought in by boat, which made them illegal entrants (a more serious offence than working on a tourist permit or a permit for visiting relatives). These women all said that they were shocked to find that they were being smuggled, as they believed that the money they had paid to the middleman had been for some sort of "legitimate" employment visa. Ah Huang [B16], who was only 17 at the time, said that even when she boarded the boat she assumed that she would pass through immigration control at some point during the trip. It was only when she found herself in a taxi on the other side of the border that she realized that she had been smuggled into Hong Kong. She said that she wanted to quit then but was too frightened by the "minders". Given the 
increased availability of visas for mainland Chinese to visit Hong Kong, it is perhaps surprising that smuggling is still being used as a mode of entry into Hong Kong. Only two other women were smuggled amongst the total sample of 58 respondents, which may indicate that smuggling is particularly prevalent in trafficking cases, adding to these women's vulnerability.

Almost all of the 12 women were immediately taken to designated "villas" (brothels, or vice establishments) and were closely supervised by a minder. The middleman, sister or boss would then inform the woman that she was expected to do sex work. They would try to put this news in a positive light, assuring each woman that she could earn money quickly if she cooperated. However, if a woman resisted, she was told that she could not leave the villa until she paid back the visa fee. For example, Ah Mui [A6] was told: "After you pay HK $\$ 6,000$ (about US\$775), you are free to go". Ah Mui told us that she was frightened because the man who told her this carried a knife under his shirt and was accompanied by a second large man. She said that she cried, but the other women in the room urged her to give in and do the sex work, advising her that there was no point in fighting back and that if she just worked for 14 days, the minders would let her go.

Some women told us that they agreed to do the sex work fairly quickly, either because they were persuaded by the promise of high earnings or because they saw little point in resisting. However, others said that they struggled with their decision for several days or weeks before agreeing to take clients. Five respondents said that they strongly objected and felt that they were ultimately forced into sex work. This is borne out by their accounts.

For example, Ah Lin [B20] was 19 years old and came to Hong Kong with her 18 year-old cousin. The two women had first travelled to Shenzhen from a rural part of Sichuan Province, hoping to find waitressing work there. They said they were robbed of all their money on the train and could not find jobs in Shenzhen. They therefore eagerly accepted when a man promised them jobs as waitresses in Hong Kong. Ah Lin said that she was surprised when they were brought to Hong Kong by boat and that they did not go through immigration control. When they arrived at the dormitory in Mongkok, the minder told them that they had to do sex work. The minder threatened them and said that the police would beat them up if they tried to escape. Ah Lin refused to work for several weeks and was locked up in the 
flat. She eventually gave in and agreed to work, serving about seven clients before she was arrested.

Ah Kai [B17] was only 15 when she was brought by boat to Hong Kong. Since she was miserable after serving the first client, the minders allowed her to leave. She asked the doorman how to get back to the mainland and he told her to take a taxi to the KCR (train) station and then a train to Lo $\mathrm{Wu}$ (on the border). She went directly to Lo $\mathrm{Wu}$ and showed her forged identity card, which ultimately led to her conviction of possession of a forged travel document.

One of the most violent stories was told by Ah Mei [B23], who we classified as a case of continuous trafficking, occurring over two trips. Ah Mei said she was tricked into coming to Hong Kong by a woman from Nanning, who promised her a foot massage job that would pay HK $\$ 10,000$ (US\$1,289) per month, more than ten times what she was earning in China. However, when she and her friend arrived in Hong Kong they were taken to a villa in Mongkok and told that they would have to do sex work. They protested but the boss slapped them and threatened to kill them, telling them that they could only leave after they had repaid him the HK $\$ 15,000$ (or US\$1,934) that it had cost to bring them to Hong Kong. The boss locked the women in their room and refused to give them food. They tried to escape when they were being moved to another villa, but were caught by minders. Finally, on the third day, the women agreed to do sex work. Ah Mei earned HK\$4,000 to HK\$5,000 (about US\$515-644) for the boss in five days, having served eight or nine clients each day. On the fifth day she had to give oral sex to a client who was quite violent and injured her throat. Ah Mei cried so much that the boss finally called the woman from Nanning to take her home. However, once she was back in Guanxi, the woman began to harass Ah Mei and her friend to repay more money, threatening to tell their families about the sex work if they did not return. Ah Mei said that she ultimately agreed to go back to Hong Kong to work and was subsequently arrested.

These cases illustrate that, after the initial deception, whereby the women were lured to Hong Kong on false promises, a variety of methods were used to persuade or force them into sex work. All of the women faced the financial pressure to pay back their visa fee, and the fear of reprisal if they could not repay it. Some women were also locked up and threatened with physical violence. The women who were smuggled into Hong Kong and/or given false identity papers were in a particularly vulnerable situation, because they were in constant fear of arrest and unable to return home 
without the assistance of their recruiters. If these women try to leave the villa and make their way back to China on their own, it is almost inevitable that they will be arrested at the border and serve substantial time in prison (as Ah Kai's [B17] case illustrates, above). ${ }^{176}$ Faced with that alternative or going to the police - many women decide to try to endure two or three weeks of sex work, in the expectation that the boss and his/her various middlemen will then help them to return to the mainland without being arrested.

In the authors' view, all of these women clearly fall within the Trafficking Protocol's definition of "victims of trafficking". Whichever interpretation of the definition is adopted, it is clear that a woman will be considered a "victim of trafficking" under the Trafficking Protocol where (a) she is recruited "by means of deception" as to nature of the job she will undertake; (b) she is ultimately forced or she ultimately consents to engage in prostitution; and (c) a third party profits from the arrangement (the "exploitation of prostitution by others" element of the definition). As discussed above, ${ }^{177}$ the Trafficking Protocol deems any apparent "consent" to be irrelevant if preceded by deception. Recognising the modern-day reality of trafficking, the Trafficking Protocol makes no distinction between women who are ultimately forced into prostitution, and women who are ultimately persuaded into prostitution, but treats both as victims of trafficking.

\subsection{Problematic Issues in the Identification of Trafficking Victims}

As well as shedding light on the nature of modern-day trafficking into Hong Kong, our study indicates that the number of women trafficked into Hong Kong is greater than officially recognized. Using the Trafficking Protocol's definition, the accounts of $21 \%$ of our total sample (12 respondents) indicate that they were "victims of trafficking". By comparison, the authorities identified only 36 women as trafficking victims between 2001 and 2006, representing a mere $0.07 \%$ of the 48,026 migrant women arrested for suspected involvement in prostitution in the same period. ${ }^{178}$ Further, the study casts doubt on the adequacy of current law enforcement measures to identify trafficking victims.

\footnotetext{
${ }^{176}$ See p. 72 above.

177 See pp. $44-45$ above.

${ }^{178}$ Statistics provided by the Hong Kong Correctional Services Department, Personal Communication, 27 April 2007.
} 
4.3.1 The Inadequacy of a Law Enforcement Response to Identifying Trafficking Victims

The 2006 Trafficking in Persons Report states that the Hong Kong government "devotes significant resources to combating trafficking, including training frontline law enforcement officials to identify trafficking victims". ${ }^{179}$ When we asked the Hong Kong Police Force (by direct reference to this statement) for details on the nature of this training, and the criteria employed for identifying trafficking victims, they replied, rather generically, that "police officers at all levels have been trained to investigate and prosecute all crime cases, including human trafficking", 180 and that potential trafficking cases are identified through "stringent enforcement actions". ${ }^{181}$ Whilst the Police Force is clearly tasked with enforcing the law, the underlying problem - highlighted by their indirect response to our question - is that law enforcement is directed only at traffickers (under the crime of trafficking) and migrant sex workers (the crime of soliciting, and various immigration offences). Identification of trafficking victims arises only as a "by-product" of the "stringent enforcement actions" taken against these two groups; there is no clear definition of trafficking victims for protection purposes, and no legal basis for a police response to trafficking victims per se.

The large majority (90\%) of the 58 women in our study were arrested by the police, usually within a few days of arrival, whilst the remainder $(10 \%)$ were arrested by immigration authorities, on average seven days after arrival. The speed of arrest reflects the significant resources devoted to law enforcement efforts against migrant sex workers. Yet, the study indicates that the tough enforcement measures taken against migrant sex workers in recent years have not been matched by a more focused approach to identification of trafficking victims amongst them. Rather, the interviews indicate that trafficking victims are routinely treated as migrant sex workers, without proper investigation into their individual circumstances. This may partly be due to the arresting authorities holding incorrect assumptions about the nature of modern-day trafficking, and the circumstances in which trafficking victims are likely to present themselves.

\footnotetext{
${ }^{179}$ TIP Report 2006, supra note 162.

${ }^{180}$ Commissioner of Police, Hong Kong Police Force, Personal Communication, 27 June 2007.

${ }^{181}$ Ibid.
} 
4.3.2 Incorrect Assumptions that Trafficked Women will "Selfidentify"

Community organizations have expressed concern that, in routine raids of vice establishments and in routine arrests at street level, the police rarely investigate whether any women have been forced into sex work, or are otherwise working under coercive conditions. ${ }^{182}$ There are at least some indications that the police expect the women's situations to present themselves as "open and shut" cases of trafficking.

First, the fact that a few trafficked women have escaped and alerted their situations to the authorities ${ }^{183}$ may have encouraged the belief that a "truly" trafficked woman will manage to escape. Certainly, senior police officials in Hong Kong's Organized Crime and Triad Bureau have previously expressed the view that women have many opportunities to escape if they are unwilling to do sex work, for example, by running away from their minder whilst going from one premise to another, or simply walking out of a villa or karaoke bar. ${ }^{184}$ Our study shows, however, that any expectation that trafficked women will escape overestimates the level of control the women have over their situations, due to the economic, psychological, and physical constraints placed on them. Only two of the 12 trafficked women in our study tried to escape: Ah Mui [A6] tried to run out of the villa, but was chased and brought back. Ah Kai [B17] walked out of her villa, unchallenged, but was then arrested at the border because she had been given false documentation by the people who brought her to Hong Kong. Three of the women were not physically able to escape, as they were locked into their rooms and/or constantly minded. The remaining seven women were theoretically able to escape, but did not attempt to do so. Four of these seven women were brought into Hong Kong illegally, and were therefore in a particularly vulnerable situation if they escaped. The other three decided that the best way out of their situation was to work to repay their visa fees.

\footnotetext{
182 Action for Reach Out, Personal Communication, 16 May 2007; Zi Teng, Personal Communication, 30 May 2007; and Ann Gray (Action For Reach Out), HKSAR Government Report on the CEDAW Convention from Action for Reach Out, paper presented at Seminar on the CEDAW Convention, Centre for Comparative and Public Law, University of Hong Kong, 28 November 1998, http://www.hku.hk/ $\mathrm{ccpl} /$ research_projects_issues/cedaw/actionforreachout.html.

${ }^{183}$ Emerton 2001, supra note 4, at 23.

${ }^{184}$ Trafficking Meeting 2003, supra note 142.
} 
Our study also undermines any expectation that trafficked women will usually "self-identify" by being found in obviously abusive circumstances at the time of arrest. Ten of the 12 women trafficked women were arrested in circumstances similar to our larger pool of 58 respondents. Ruby's [A29] case represents a standard "street" arrest. She was eating breakfast when a man approached her, and "hinted at sex work". She told him that the price was HK\$100, and he followed her back to her room. At that point, he showed his police ID and arrested her for soliciting. Joey's [A3] account was typical of the "villa" arrests. Her client asked her to take her clothes off, whilst he went for a shower. When he came out, he paid her $\$ 450$ in advance, and a few minutes later showed his police ID and arrested her for breach of condition of stay. The only immigration arrest amongst the 10 cases followed a routine documentation check in the villa. In all these cases it would not have been apparent to the arresting officers, without further investigation, that the women might have been trafficked, as their circumstances would not have sent out any immediate warning signals. Instead, they appeared to be typical migrant sex worker cases, and were treated as such, with all the women being prosecuted and sent to prison.

The other two trafficked women were arrested in circumstances which should have alerted the arresting officers to the possibility that they had been trafficked, but even their cases were not subject to further investigation, which gives particular cause for concern. Ah Pik [B2] was working in a factory when she was recruited to work as a waitress in Hong Kong, but was then smuggled into Hong Kong illegally, by boat. When she arrived, she was taken to a villa and locked up in a small room. She was forced to take clients from the second day, but kept crying. Some of the clients were kind and decided not to have sex with her. This irritated the boss, who threatened to beat her up and told her that she must repay the money for the boat trip. On the fourth day, the police raided the villa and broke the outside lock to Ah Pik's room. The police officer told her that if she called her boss to get her visa, she might not have to go to jail (there would have been insufficient evidence to charge her for breach of condition of stay, since she was not with a client when she was arrested). As she was not able to produce any documentation, however, she was arrested. Even though the police had to break open a lock on the outside of the door in order to arrest Ah Pik, her circumstances do not appear to have been further investigated, and she was processed in the usual manner, ultimately receiving a 10 -month sentence for remaining in Hong Kong without authority. 
Ah Mui [A6] was promised a job in a beauty salon. When Ah Mui arrived in Hong Kong, she initially refused to do sex work, but ultimately felt threatened into it. Her minders took her to different villas, where the clients would choose from a selection of women (so-called "goldfish watching"). Ah Mui said she deliberately covered herself with her jacket, to avoid being selected. The first time she was chosen by a client (who turned out to be an undercover police officer), she ran downstairs and tried to leave the villa. She was chased by the minder and brought back to the room. Ah Mui then told the "client" that she had been deceived and did not want to work as a prostitute. He asked her to take off her clothes, but she refused. He eventually took off his own clothes, had a shower, and asked for a massage. When Ah Mui said she did not know how to give a massage, the "client" dressed and revealed that he was a police officer. She told him that she had been cheated and repeated her story at the police station. The police officers comforted her when she cried, but also told her that she had been very stupid. She was sent to court and sentenced to two months' imprisonment for breach of condition of stay.

These cases indicate that the authorities need to adopt a more pro-active investigation of women's circumstances in routine arrests of migrant sex workers, with a view to identifying potential trafficking victims. They also need to be more alert to obvious signs of abuse. In particular, a better understanding of the modern-day nature of trafficking into Hong Kong might help educate front-line officers on the economic, physical and economic circumstances which can trap trafficked women into compliance, and debunk any preconceived notions that trafficked women will escape or "self-identify" as trafficked.

\subsection{The Fate of Trafficking Victims who are treated as Migrant Sex Workers}

Our study shows that, in response to the huge increase in mainland Chinese sex workers in recent years, Hong Kong has developed a highly standardized system for processing migrant women who are suspected of engaging in sex work. This system can aptly be described as a "migrant sex worker conveyor belt", one that takes women from the police station, through the courts, and invariably to prison. The system has minimal flexibility to take into account, and respond appropriately, to the circumstances of trafficking victims. Rather, the interviews indicate that a woman who is not immediately identified as trafficked will have little, if any, opportunity to avoid prosecution: once arrested she will be treated as a typical migrant sex worker case and the wheels of the bureaucratic 
criminal justice machine will start to turn. The following discussion highlights some key problem areas at the police station and courts. ${ }^{185}$

After arrest, all the women were taken to the police station. The experiences of the broader sample of 58 women indicate that, whilst the correct formalities are usually complied with, the statement-taking process is quick, with limited regard for individual circumstances. The majority of respondents were provided with an interpreter, and, after being interviewed, were asked to sign a written statement. One of the trafficked women said, however, that she was not interviewed or questioned, but was simply asked to sign a pre-prepared statement. In our broader sample, some women also complained that they signed statements which they could not read, because they were in English and traditional Chinese (whereas the written language taught in China is simplified Chinese). Senior police officers have recognized that this is a problem. ${ }^{186}$ Three of the 12 trafficked women reported that they had specifically informed the police of the deception and force used in their cases, but with little effect. For example, Ah Lin [B20] told the interviewer that she not only informed the police that she had been forced to do sex work, but that she also told the police that her cousin had been deceived with her and was still under the control of the organization. At the time of her interview, she had no idea whether the police had taken any action to locate and rescue her cousin. Similarly, Ah Mei [A23] told the interviewer that she had tried to explain to the police how she had been deceived and then forced into sex work, and that a friend who had travelled with her was still under the control of the boss. She felt that nobody was interested in her story and said that even a social welfare officer discouraged her from repeating it, advising Ah Mei that her friend would have to go to jail if she was "rescued" by the police.

Unfortunately, the free services of a duty lawyer are not available at the police station, and none of the women was assisted by a lawyer or NGO ${ }^{187}$ during the statement-taking process.

After being interviewed at the police station, all the women in our study were remanded in custody and sent to a magistrates' court the next working day. Whilst most women's cases were dealt with individually,

\footnotetext{
${ }^{185}$ For further detail on the broader sample's experiences of the criminal justice system, see Laidler et al, supra note 3.

${ }^{186}$ Discussion at Round Table 2006, supra note 125.

${ }^{187}$ Two sex worker organizations are known to leaflet and advise local and migrant sex workers about their rights, and are sometimes called upon to represent migrant sex workers at the police station. Discussions with Action for Reach Out and Zi Teng, July 2006.
} 
some respondents (five in total, including one trafficked woman) reported that their cases were processed as part of a group, both before the duty lawyer (the equivalent of a public defender) and the magistrate (judge). ${ }^{188}$ By definition, this group treatment must have hindered individual consideration of these women's cases.

All 12 trafficked women were offered the services of a duty lawyer. One woman refused this service, as she simply wanted to plead guilty and get the case behind her. The remaining 11 uniformly reported that they had the opportunity - albeit, in some cases, very brief - to speak to the duty lawyer about their circumstances, including their economic situations at home, and the use of deception and/or force in their cases. Even those women who recounted extreme circumstances to the duty lawyer were still prosecuted. Their accounts did not invoke further investigation. Nor is there any indication that the prosecution might drop a case once it has reached the court, and is "in the system". Rather, the women's circumstances were simply raised by the duty lawyer in mitigation, i.e. in an effort to reduce the standard sentence for the offence(s), after conviction. The Administrator of the Duty Lawyer Service advised us that this is standard procedure, and stated that, even if a woman alleges that she was deceived or forced into sex work, these circumstances are "considered mitigating factors and not a defence by the court". ${ }^{189}$

Our study showed that migrant sex worker cases are handled very swiftly by the courts. From our court observations, the average time to complete each defendant's case before the judge was only three minutes, and some women reported that they struggled to understand the judge, or the interpreter, due to the speed at which the case was processed.

All of the 12 trafficked women in our study pled guilty, including the five who alleged that they were forced into sex work. Some felt that the duty lawyer encouraged them to plead guilty. Ah Lin [B20], for example, said that she told the duty lawyer that she had been deceived and forced into sex work but that he advised that no one would believe her and encouraged her to plead guilty, promising that he would ask for a lighter sentence. Ah Shaw [B8], who was interviewed in a group of eight women, also reported that the lawyer "persuaded the girls to plead guilty". A community

\footnotetext{
${ }^{188}$ The Administrator of the Duty Lawyer Service has confirmed that this may occur, inter alia where (a) defendants are arrested together, but charged separately, and (b) their mitigation is related and thus interviewing them together would serve their best interests, Personal Communication, 21 February 2006.

${ }^{189}$ Ibid.
} 
organisation which regularly helps migrant sex workers negotiate the court process told us that, in their experience, the duty lawyers are meticulous in setting out the options, and likely results, in a neutral manner. ${ }^{190}$ It is important to remember that since the use of deception and force is not regarded as a defence, there is currently no legal basis for a trafficked woman to plead "not guilty", unless she can challenge the elements constituting the offence, e.g. that she was not soliciting at the time of her arrest, or that she not working at the time of her arrest and therefore not in breach of her conditions of stay. The duty lawyer is also obliged to review the options, and to point out the standard sentence associated with a guilty plea (which usually results in a one-third discount), as compared to the long wait for a trial for a not-guilty plea (indeed, the wait is often longer than serving the sentence for a guilty plea). It is therefore possible that some women were persuaded by the practical realities of the options presented to them, rather than by the duty lawyers themselves. Indeed five women in our broader sample pled not guilty, on the basis that they were not soliciting or working at the time of arrest, but subsequently changed their plea to guilty, after hearing from other women in prison that a trial would only delay their return home.

On pleading guilty, all of the 58 respondents, including the 12 trafficked women, received immediate custodial sentences. The standard sentences following a guilty plea were: one to two months' imprisonment for soliciting; two to three months for breach of condition of stay (alone or combined with soliciting); ten months for remaining in Hong Kong without authority (i.e. for being illegally smuggled into Hong Kong), and up to 14 months when this latter offence was combined with possession of a forged travel document. According to a senior retired magistrate, some magistrates previously gave suspended sentences to first time offenders. This practice apparently met with disapproval, however, and has since been discontinued. ${ }^{191}$

All of the 11 trafficked women who accepted the services of a duty lawyer said that the duty lawyer duly put their circumstances to the magistrate in mitigation. However, their sentences were generally not reduced beyond the standard one-third discount for a guilty plea. Only two of the 12 trafficked women were given further discounts on the standard sentences for the relative offences, probably due to their young age. Ah Huang [B16], who was 17 at the time of arrest, received a 10-month sentence for

\footnotetext{
${ }^{190}$ Meeting with Action for Reach Out, July 2006.

${ }^{191}$ Comment of retired magistrate at Round Table 2006, supra note 125.
} 
remaining in Hong Kong without authority and possession of a forged travel document, compared to the standard 14-month sentence for this combination of offences. Ah Kai [B17], who was only 15 at the time of arrest (and therefore below the statutory age of consent to sexual intercourse in Hong Kong), received a six-month sentence for the same combination of offences. Sadly, this suggests that magistrates are becoming hardened to the women's individual circumstances, due to the large volume of cases before them.

The situation in which trafficking victims are placed is clearly unacceptable. The Hong Kong authorities are willing to grant immunity to trafficked women who assist in the prosecution of their traffickers. ${ }^{192}$ The same immunity should be available to women who are initially prosecuted as migrant sex workers, but who are then revealed to be trafficking victims. Continuing to prosecute such women, and to imprison them for offences they committed as a result of being trafficked, not only violates their human rights, but also brings into question the genuineness of Hong Kong's commitment to protecting and assisting trafficking victims.

\section{Conclusion and Recommendations}

Since the Trafficking Protocol has only recently been adopted, it is highly unlikely that there will be an opportunity for an international, human rights-based trafficking convention in the foreseeable future. Regrettably, this means that the international response to victim protection will probably remain focused on trafficking in a transnational organized crime context, and state parties will continue to have considerable discretion as to the nature and level of protection they provide to trafficking victims.

At the Asia-Pacific regional level, NGOs should be encouraged to sustain their efforts to strengthen victim protection in existing anti-trafficking instruments. In particular, they should work to ensure that SAARC fulfils its promise to review the SAARC Convention, and should call on ASEAN to infuse a human rights approach into the rather skeletal $A S E A N$ Declaration, on the basis of its new Charter-based commitment to human rights in the region. NGOs could also usefully lobby states to uphold their commitments under the human rights-based ARIAT Action Plan, which has been under-utilized to date.

192 Trafficking Meeting 2003, supra note 142; see also TIP Report 2007, supra note 161. 
At the domestic level, states should be urged to place human rights at the core of their efforts to prevent and combat trafficking, and to protect trafficking victims, as recommended by the High Commissioner for Human Rights in the Recommended Principles and Guidelines on Human Rights and Trafficking. ${ }^{193}$ The United States' annual Trafficking in Persons report is one way to pressure governments. This study indicates that the "tier one" status given to Hong Kong should be reconsidered unless and until Hong Kong makes a greater effort to identify and assist victims of trafficking.

The Hong Kong government has credible protection policies for trafficking victims, which largely meet the standards contained in the ARIAT Action Plan and the Trafficking Protocol. However, the authorities identify only a handful of women as trafficking victims each year. Our study indicates that Hong Kong's trafficking problem is greater than acknowledged, and that the increased emphasis on arresting and imprisoning mainland Chinese sex workers in recent years has not been matched with a more focused identification of trafficked women. In particular, migrant women arrested in routine raids and street arrests are rarely identified as trafficked. Instead these women are caught in a system developed for migrant sex workers - one that is highly standardized to cope with the high volume of cases, and invariably leads to prison. Women's accounts of deception, force or coercion are treated merely as mitigating factors, and even then, rarely lead to a reduction in the standard length of sentence. As a result, women as young as 15 can serve lengthy sentences for their naivety in following false promises to Hong Kong, and for not finding the opportunity or motivation to escape from coercive situations.

This article does not make recommendations relating to Hong Kong's response to migrant sex workers in general, although this policy would also benefit from review. ${ }^{194}$ The authors do not recommend, however, that the government treat all migrant sex workers as trafficking victims, as advocated by radical feminists. The authors share the view of pro-sex work feminists that such a stance would fail to respect women's choice and agency in deciding to migrate for sex work. Given the phenomenal number of migrant sex workers in Hong Kong, the abolitionist approach would also dilute efforts towards those women who are trapped in immediately coercive conditions, and in urgent need of protection. It might also backfire, and fuel an increase in trafficking, as traffickers might use the

\footnotetext{
${ }^{193}$ High Commissioner's Principles and Guidelines, supra note 112, Principle 1.

194 See Laidler et al, supra note 3, which questions the actual deterrent effect of Hong Kong's current criminal justice response to migrant sex workers.
} 
lack of penalty, and availability of repatriation, as part of their marketing strategy. ${ }^{195}$ The government might also fall back on immigration policy, to restrict the entry of young mainland Chinese women into Hong Kong. ${ }^{196}$

The Hong Kong government should adopt an official policy statement, or ideally a specialist law (such as that adopted in the USA), ${ }^{197}$ which provides for the protection and assistance of trafficking victims, and is independent from the criminal regime established for the prosecution of traffickers. This policy or law should be based on a clear definition of trafficking victims, which properly reflects the nuances of modern-day trafficking into Hong Kong, and also takes into account (but not necessarily replicates) the internationally accepted definition of "victims of trafficking" contained in the Trafficking Protocol. Such a definition should encompass not only persons forced into prostitution, but also those who, whilst apparently consenting to engage in prostitution, are led to that point through coercion, abduction, fraud, deception, or the abuse of power. The nebulous term "abuse of a position of vulnerability" should not be included unless it is accompanied by a clear definition of the term, which is absent in the Trafficking Protocol. (The Philippines government reproduced the Trafficking Protocol definition verbatim in its 2003 anti-trafficking law, and that law now suffers from the same lack of clarity. $)^{198}$

Armed with a clear definition of trafficking victims and their rights, the Hong Kong authorities should then make a greater effort to identify trafficked women, particularly those arrested during routine raids. Further training of police and immigration officers is required to (re-)educate them as to the circumstances in which trafficked women might find themselves, and to debunk any assumption that trafficked women will escape or "self identify" by being found in obviously abusive circumstances. Whilst it is perhaps inevitable that the police and courts have developed standard procedures to cope with the large number of migrant sex workers arrested, it is imperative that trafficking victims be given the opportunity to step off what can only be described as a "migrant sex worker conveyor belt". When women allege circumstances that might amount to trafficking (at whatever stage in the proceedings), the authorities should properly investigate their cases and, where relevant, drop the prosecution against

\footnotetext{
${ }^{195}$ See Fitzpatrick, supra note 110 , at 1157.

${ }^{196}$ See Special Rapporteur VAW 2000 Report, supra note 16, paras 42, 47 and 89-97.

197 Trafficking Victims Protection Act of 2000, Pub.L.No. 103-386, 114 Stat. 1464.
}

198 Anti-Trafficking in Persons Act 2003, Republic Act 9208, http://www.chanrobles.com/republicactno9208.html. 
them. These women should then be offered the protection and assistance due to them.

Both the General Assembly ${ }^{199}$ and the former High Commissioner of Human Rights have called on states to adopt a national action plan on trafficking. ${ }^{200}$ The Security Bureau, which is tasked with co-ordinating Hong Kong's anti-trafficking efforts, inevitably has border control and law enforcement as its primary concerns. Adopting a formal action plan on trafficking - with due consultation of relevant bodies, including NGOs might help integrate a human rights approach into Hong Kong's antitrafficking efforts. A number of Asia-Pacific countries have already adopted such plans, including Australia, ${ }^{201} \mathrm{Japan}^{202}$ the Philippines ${ }^{203}$ and Vietnam. $^{204}$ The reforms recommended in this article would almost certainly be facilitated if China, and through it Hong Kong, would become party to the Trafficking Protocol. Although the Trafficking Protocol arguably would not apply to mainland Chinese women trafficked into Hong Kong (on the ground that such trafficking is technically not transnational), it would demonstrate China's and Hong Kong's commitment to the global fight against trafficking, and to the protection of its victims.

${ }^{199}$ General Assembly Resolution on Trafficking in Women and Girls, supra note 33, at para 5.

200 Ibid, at para 5; High Commissioner's Principles and Guidelines, supra note 112, Guideline 1(3).

${ }^{201}$ Australian National Action Plan to Combat Trafficking in Persons (June 2004).

${ }^{202}$ Japan's Action Plan of Measures to Combat Trafficking in Persons (December 2004).

${ }^{203}$ Philippines Government launches a National Action Plan against Trafficking in Human Beings, UNIS/CP/398 30 October 2001, http://www.unis.unvienna.org/unis/pressrels/2001/ cp398.html.

204 Vietnam's Action Plan was adopted in July 2004, see http://www.humantrafficking.org/countries/vietnam. India has also recently announced plans to adopt a national action plan, see e.g. "Action Plan to Combat Trafficking", The Hindu, 10 October 2007; and "National Action Plan for Combating Trafficking on the Anvil", Indian Catholic, 10 October 2007. The PRC has drafted, but not yet adopted an action plan, see "China Issues Plan to Combat Trafficking", People's Daily Online, 13 July 2006 and Trafficking in Persons Report 2007: People's Republic of China (under a 2004 Sub-Regional Plan of Action, the PRC, Cambodia, Laos, Burma/Myanmar, Thailand and Vietnam agreed to devise national plans of action). 